\title{
Growth Hormone(s), Testosterone, Insulin-Like Growth Factors, and Cortisol: Roles and Integration for Cellular Development and Growth With Exercise
}

\author{
William J. Kraemer ${ }^{1 *}$, Nicholas A. Ratamess ${ }^{2}$, Wesley C. Hymer ${ }^{3}$, Bradley C. Nindl ${ }^{4}$ and \\ Maren S. Fragala ${ }^{5}$ \\ ${ }^{1}$ Department of Human Sciences, The Ohio State University, Columbus, $\mathrm{OH}$, United States, ${ }^{2}$ Department of Health and \\ Exercise Science, The College of New Jersey, Ewing, NJ, United States, ${ }^{3}$ Biochemistry and Molecular Biology, \\ The Pennsylvania State University, University Park, PA, United States, ${ }^{4}$ Department of Sports Medicine, School of Health and \\ Rehabilitation Sciences, University of Pittsburgh, Pittsburgh, PA, United States, ${ }^{5}$ Quest Diagnostics, Secaucus, NJ, \\ United States
}

OPEN ACCESS

Edited by:

Flavio Adsuara Cadegiani, Federal University of São Paulo, Brazil

Reviewed by:

Michaël R. Laurent, University Hospitals Leuven, Belgium

Gwen V. Childs,

University of Arkansas for Medical

Sciences, United States

*Correspondence:

William J. Kraemer

kraemer.44@osu.edu

Specialty section: This article was submitted to Translational Endocrinology, a section of the journal

Frontiers in Endocrinology

Received: 19 November 2019

Accepted: 16 January 2020

Published: 25 February 2020

Citation:

Kraemer WJ, Ratamess NA

Hymer WC, Nindl BC and Fragala MS

(2020) Growth Hormone(s),

Testosterone, Insulin-Like Growth

Factors, and Cortisol: Roles and Integration for Cellular Development

and Growth With Exercise.

Front. Endocrinol. 11:33.

doi: 10.3389/fendo.2020.00033
Hormones are largely responsible for the integrated communication of several physiological systems responsible for modulating cellular growth and development. Although the specific hormonal influence must be considered within the context of the entire endocrine system and its relationship with other physiological systems, three key hormones are considered the "anabolic giants" in cellular growth and repair: testosterone, the growth hormone superfamily, and the insulin-like growth factor (IGF) superfamily. In addition to these anabolic hormones, glucocorticoids, mainly cortisol must also be considered because of their profound opposing influence on human skeletal muscle anabolism in many instances. This review presents emerging research on: (1) Testosterone signaling pathways, responses, and adaptations to resistance training; (2) Growth hormone: presents new complexity with exercise stress; (3) Current perspectives on IGF-I and physiological adaptations and complexity these hormones as related to training; and (4) Glucocorticoid roles in integrated communication for anabolic/catabolic signaling. Specifically, the review describes (1) Testosterone as the primary anabolic hormone, with an anabolic influence largely dictated primarily by genomic and possible non-genomic signaling, satellite cell activation, interaction with other anabolic signaling pathways, upregulation or downregulation of the androgen receptor, and potential roles in co-activators and transcriptional activity; (2) Differential influences of growth hormones depending on the "type" of the hormone being assayed and the magnitude of the physiological stress; (3) The exquisite regulation of IGF-1 by a family of binding proteins (IGFBPs 1-6), which can either stimulate or inhibit biological action depending on binding; and (4) Circadian patterning and newly discovered variants of glucocorticoid isoforms largely dictating glucocorticoid sensitivity and catabolic, muscle sparing, or pathological influence. The downstream integrated anabolic and catabolic mechanisms of these hormones not only affect the ability of skeletal muscle to generate force; they also have 
implications for pharmaceutical treatments, aging, and prevalent chronic conditions such as metabolic syndrome, insulin resistance, and hypertension. Thus, advances in our understanding of hormones that impact anabolic: catabolic processes have relevance for athletes and the general population, alike.

Keywords: anabolic, catabolic, protein synthesis, skeletal muscle, endocrine, glucocorticoid, androgen, signaling

\section{INTRODUCTION: THE COMPLEXITY OF HORMONE SIGNALING}

Cell signaling may be described as a critical part of communication that governs basic activities of cells and coordinates all cellular actions. Hormonal signaling is part of a complex system involving a plethora of molecules. The actions and potency of any hormone will be affected by all components of the signaling chain (Figure 1). Depending on the cellular environment and negative feedback control, some components of the chain may be more proactive in eliciting a response or adaptation. To make a simple analogy, hormone signaling is analogous to playing a team sport. All players on the team have distinct roles and responsibilities during each play. Success depends on how well the team executes and communicates in an integrative manner to carry out team objectives. Hormones work in a similar manner. All stages from production, release, transportation, tissue uptake, and intracellular signaling must be considered in an integrative manner to accurately portray the effects of the hormone-receptor interaction (1). Thus, viewing only a fraction of the signaling chain may underrepresent the entirety of the hormonal actions. Science has shown the great complexity of hormonal signaling as strides have been made in cell biology and biochemistry.

\section{TESTOSTERONE SIGNALING PATHWAYS, RESPONSES, AND ADAPTATIONS TO RESISTANCE TRAINING}

Testosterone $(\mathrm{T})$ is an anabolic-androgenic steroid hormone that primarily interacts with androgen receptors (AR) in skeletal

Hypothalamic/Pituitary/Gonadal Axis

Kisspeptin, GnRH, LH<smiles></smiles>

Androgen Systemic Concentrations \& Responses

Transport Protein Binding, Tissue Uptake

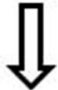

Skeletal Muscle Steroidogenesis

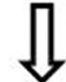

Intramuscular Signaling

Genomic, Non-Genomic, Satellite Cells (Myogenesis), Anti-Catabolism, $\beta$-Catenin, MAPKs, mTOR, Notch, microRNAs, $\mathrm{Ca}^{++}$(acute contractility)

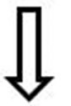

Androgen Receptor (AR)

Up- \& Down-Regulation, Phosphorylation, Ligand Binding \& Stabilization, Hormonal Cross-Regulation

Genetic Polymorphisms \& Response

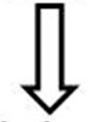

AR Transcriptional Potency

Stabilization \& DNA Binding, Co-Activators, Ribosomal Biogenesis

FIGURE 1 | Potential sites of augmented androgen signaling responses or adaptations to resistance exercise. 
muscle whereas the more-potent dihydrotestosterone (DHT) primarily acts within sex-linked tissues with a possible secondary role in skeletal muscle (2) Although skeletal muscle content of DHT has been correlated to muscle strength and power (3), T replacement with and without dutasteride or finasteride (5 $\alpha$-reductase inhibitors) produces similar increases in lean tissue mass and muscle strength $(4,5)$. Thus, it is currently unclear if DHT is more anabolic in skeletal muscle than T alone. Testosterone performs a multitude of ergogenic, anabolic, and anti-catabolic functions in skeletal muscle and neuronal tissue leading to increased muscle strength, power, endurance, and hypertrophy in a dose-dependent manner (1). Genomic androgen/AR binding may alter the expression of more than 90 genes, several of which are involved in the regulation of skeletal muscle structure, fiber types, metabolism, and transcription (6). Studies show androgens increase protein synthesis rates, and reduce protein catabolism and autophagy (7). Castration reduces several markers of ribosome biogenesis that may only be partially restored by androgen treatment coupled with castration (8). In addition, evidence indicates that androgens may play a role in stimulating physical activity in males (9). Thus, androgens play important roles, in part, in mediating skeletal muscle protein synthesis and adaptations to resistance training (RT).

The primary androgen, $\mathrm{T}$, is synthesized from cholesterol and other precursors in the Leydig cells of the testes ( $>95 \%$ in men with some adrenal contributions) under control of the hypothalamic-anterior pituitary-gonadal axis where gonadotropin releasing hormone $(\mathrm{GnRH})$ stimulates the release of luteinizing hormone (LH) from gonadotrophs. GnRH functions under the control of hypothalamic neuropeptides such as kisspeptins, neurokinin-B, dynorphin- $A$, and phoenixins $(10,11)$. Kisspeptin (a 54 amino acid peptide) is encoded from the KISS1 gene and is released from neurons within the arcuate nucleus and anteroventral periventricular nucleus of the hypothalamus as well as other tissues outside of the CNS. Kisspeptin binds to KISS1R (GPR54) receptors on GnRH neurons and causes the release of GnRH (via a G-protein 2nd messenger system). Hypothalamic neuropeptide expression is dependent on metabolic status (12); however, little is known regarding exercise responses. Khajehnasiri et al. (13) examined moderate vs. intense treadmill training for 6 months in rats and showed intense exercise (but not moderate) led to decreased GnRH mRNA and serum total T (TT) and LH. No differences were seen in kisspeptin mRNA although some differences were seen neurokinin-B and pro-dynorphin mRNA. Short-term administration of kisspeptin (Kp-54) or kisspeptin analogs (i.e., $\mathrm{Kp}-10$ ) increase LH and TT in a dose-dependent manner in men with increases in LH but little change in TT in women $(11,14)$.

In women, ovarian and adrenal production of androgens are major sources (15). Skeletal muscle contains the enzymes and produces small amounts of androgens $(16,17)$. Testosterone is released into circulation and transported mostly by sex hormone-binding globulin (SHBG) (44-60\%) and loosely-bound to albumin or other proteins. Free (unbound, up to $2 \%$ in circulation) $\mathrm{T}$ (FT) is taken up by tissues for binding to membrane-bound or cytoplasmic ARs and subsequent cellular signaling. However, some evidence suggests the possibility of an alternative mechanism to the "free hormone" hypothesis where membrane-bound receptor proteins (e.g., megalin-a lowdensity lipoprotein endocytic receptor) have been identified in multiple tissues including skeletal muscle, although the ability to internalize the bound steroid hormone complex and enable uptake via endocytosis still remains to be elucidated $(18,19)$. Nevertheless, SHBG concentrations influence T binding capacity and FT available for diffusion across the cell membrane. The presence of G-protein coupled receptors for SHBG in skeletal muscle membranes has been suggested to influence (i.e., inhibit or stimulate) non-genomic androgen signaling via modulation of adenylate-cyclase with cAMP synthesis and activation of protein kinase A (20), although it is currently unclear as to the magnitude of, if any, impact it may have during androgen signaling. Some $\mathrm{T}$ is converted to the more potent DHT via $5 \alpha$ reductase. This enzyme is present in skeletal muscle and circulating DHT can diffuse into muscle cells and bind to ARs with higher affinity than T. Some T is aromatized to estrogens, and final metabolism of T occurs in the liver and kidneys where inactivated metabolites are excreted in urine.

The responses of $\mathrm{T}$ to $\mathrm{RT}$ in men and women have been extensively reviewed $(2,21)$. Most studies show significant elevations of TT and FT in men through $30 \mathrm{~min}$ into recovery with few changes in resting baseline concentrations. In women, studies show no or limited acute elevations. The magnitude of the acute responses is affected by many factors including the demands of the protocol, nutritional intake, training experience but mostly due to plasma volume reductions and reduced clearance (1). The ramifications of acute elevations during RT are unclear but appear to be part of the macro-signaling cascade affecting, in part, muscular adaptations. Some studies indicate relationships between $\mathrm{T}$ elevation and $\mathrm{AR}$ up-regulation, strength and hypertrophy enhancement (22-25) whereas other reports indicated no such relationships (26). These conflicting results demonstrate the complexity of hormonal responses and the likelihood several factors are contributing to the response. Acute $\mathrm{T}$ responses must be viewed within the context of multiple skeletal muscle signaling pathway adaptations as well the wellknown interaction between $\mathrm{T}$ signaling and other hormone signaling pathways involving the GH isoforms and aggregates, IGF-I and mechano-growth factor (MGF), insulin, and cortisol responses (27-29).

\section{SKELETAL MUSCLE STEROIDOGENESIS}

Skeletal muscle steroidogenesis from DHEA is another potential source of $\mathrm{T}$ (16). Steroidogenic enzyme content and $\mathrm{T}$ concentrations in skeletal muscle are similar between men and women (17). In older men, 12 weeks of RT increases skeletal muscle DHEA, FT, DHT, 3 $\beta$-hydroxysteroid dehydrogenase

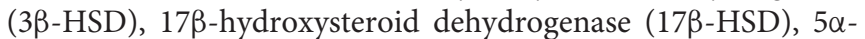
reductase type I content, and AR protein content (30). The increased DHT and FT were related to increased isokinetic strength, muscle CSA, and power (30). However, RT studies in younger men and women show no changes in muscle $\mathrm{T}$ or steroidogenic enzymes $(17,31)$. However, responders to RT were 
shown to increase $5 \alpha$-reductase (31). It is possible that increased muscle steroidogenesis may be a mechanism to help counteract $\mathrm{T}$ reductions in older men undergoing RT but less likely in healthy, young men.

\section{ANDROGEN SIGNALING PATHWAYS}

Historically, androgen signaling was thought to be governed predominately by classical genomic signaling common to steroids and steroid receptors. FT or DHT (or other synthetic anabolic steroid) binds to a cytoplasmic AR, dissociates from heat shock proteins, and the complex translocates to the nucleus to bind to specific androgen response elements on DNA. The androgen/AR complex serves as a transcription factor leading to protein synthesis with the help of co-activator proteins. Prior to androgen stimulation of skeletal muscle tissue, higher order muscle tissue activation is needed. Increased muscle strength, power, endurance, and hypertrophy resulting from RT begins with neural stimulation and the optimal recruitment of motor units based on the size principle. Androgen signaling increases neural transmission, neurotransmitter release, motoneuron cell body and dendrite size, and regrowth of damaged peripheral nerves (32). Androgen signaling in cerebral neurons is needed to maintain muscle mass in fast-twitch muscles despite elevations in circulating $\mathrm{T}$ (33). This may be regulated by reduced spontaneous locomotor activity. Thus, the RT stimulus is critical to activation of muscle tissue and the role of androgens in enhanced neural drive warrants further study. Genomic signaling accounts for a large magnitude of androgen actions; however, a number of other signaling pathways have been identified demonstrating the complexity of androgen signaling its impact on skeletal muscle development.

Non-genomic AR signaling has been a topic of interest and debate in recent times. Non-genomic actions are rapid with short latency periods acting independently (mostly at the cell membrane and cytoplasmic levels) of nuclear receptors (20). Non-genomic effects are thought to be mediated by direct binding to a target molecule, through intracellular AR activation (i.e., Src kinase), through a transmembrane AR receptor, or via changes in membrane fluidity (20). Non-genomic signaling may involve G-protein 2nd messenger system signaling. Non-genomic signaling may increase intracellular calcium concentrations (possibly affecting contractile properties) (34), stimulate activation of MAPK signaling (35), and mammalian target of rapamycin (mTOR) pathway signaling (36). Binding of bound or unbound T to ARs activate G-protein-linked receptor that activates $\mathrm{PI} 3 \mathrm{~K}$ and phospholipase $\mathrm{C}$, increases $\mathrm{IP}_{3}$ which binds to receptors on the sarcoplasmic reticulum to liberate calcium. Calcium may activate Ras/ERK1/2 pathway signaling (34). Castration reduces Akt/mTORC1 signaling and AR protein expression whereas nandrolone decanoate administration has the opposite effect (37). Basulato-Alarcon et al. (36) showed T increased MTORC1/S6K1 pathway signaling possibly through PI3K activation of Akt. Zeng et al. (38) reported DHT implantation plus exercise in rats for 10 days increased AR and IGF-I mRNA and AR phosphorylation (Ser210). They reported greater muscle hypertrophy via mTOR signaling and suggested cross-talk between IGF-I signaling and nongenomic AR signaling was critical to the augmented combined effects. Non-genomic signaling occurs rapidly within seconds to minutes, much faster than classic genomic signaling which takes hours, and requires constant presence of androgens to maintain intracellular signaling. It is unclear if the increased intracellular calcium enhances force production (35). The impact of non-genomic signaling to training-related adaptations remains unclear; however, it appears the interaction between genomic and non-genomic signaling pathways appear critical to maximizing muscle hypertrophy (36). MAPK signaling may phosphorylate the AR increasing its transcriptional capacity.

Testosterone may be anti-catabolic by either decreasing glucocorticoid receptor (GR) expression, interfering with cortisol binding, or the AR-T complex may compete with cortisol-GR complex for Cis-element binding sites on DNA (and vice versa). DNA binding domains and ligand binding domains between the AR and GR are 79 and 50\% homologous. Glucocorticoids increase expression of atrophy-related genes (i.e., atrogin-1, MuRF1, and forkhead box 01) and androgens reduce atrogene expression, reduce GC-related IGF-I expression inhibition, and down-regulate GR expression in skeletal muscle and muscle satellite cells (39).

Androgens mediate some anabolic functions through myogenesis via multiple pathways. Satellite cells and myoblasts possess ARs and androgen binding increases satellite cell activation, proliferation, mobilization, and differentiation, and incorporation into skeletal muscle (40). Androgens increase myogenesis via increased Notch signaling of satellite cells possibly due to reduced myostatin and increased Akt activation (41) and through increased expression of IGF-I in satellite cells and muscle fibers (28). Androgen binding to ARs on mesenchymal pluripotent cells increases their commitment to myogenesis rather than adipogenesis (42). Androgens may increase follistatin expression and decrease or increase myostatin and down-regulate or up-regulate its gene expression, downregulate Acvr2b receptor mRNA and Smad 2/3 phosphorylation, decrease myostatin signaling molecules, increase myogenic marker up-regulation, e.g., MyoD, myogenin, myotube formation, and myonuclei number and central positioning $(39,42,43)$.

Genomic androgen/AR binding may enhance muscle performance via stimulating the Wnt- $\beta$-catenin pathway. Wnt binds to frizzled/lipoprotein receptor protein 6 receptors and activates disheveled and inhibits glycogen synthase kinase-3 (GSK-3) reducing $\beta$-catenin dephosphorylation and increases its activity. The FT-AR complex inhibits GSK-3 and increases $\beta$-catenin where it translocates to the nucleus, binds to DNA response elements (T-cell factor/lymphoid enhancer factor 1 -TCF/LEF), increases transcription, and activation of muscle satellite cells. As $\beta$-catenin lacks a nuclear localization sequence and needs cytosolic proteins with a sequence to assist in translocation, androgen/AR complex may chaperone $\beta$-catenin to the nucleus where it binds to specific DNA elements. The presence of $\mathrm{T}$ increases AR- $\beta$-catenin interaction and transcriptional capacity. Positive correlations were shown 
between AR protein content and Wnt5 expression and muscle mass and Wnt5 expression in rats (44). Testosterone treatment increased Wnt5 protein expression and muscle size in a dosedependent manner (44). Spillane et al. (45) reported significant up-regulation of VL muscle $\beta$-catenin following upper and lower body RT at 3 and $24 \mathrm{~h}$ PE and increased AR-DNA binding capacity and suggested the increased binding capacity was linked to greater $\beta$-catenin pathway signaling.

\section{THE IMPORTANCE OF ANDROGEN SIGNALING FOR MUSCLE STRENGTH AND HYPERTROPHY}

Human and animal studies (using a variety of research models) demonstrated the importance of androgens for maintaining and increasing skeletal muscle strength and mass. Muscle strength and mass are reduced significantly (by up to 20\%) in male AR knockout mice (6). In satellite cell-specific AR knockout mice, type II to I fiber conversions and reduced muscle strength have been shown (2014). Other muscle-specific AR knockout mice models have shown reduced lean tissue mass and fast-to-slow fiber type conversion without concomitant changes in muscle strength (46). Inoue et al. (47) showed that administration of an AR antagonist in rats (oxendolone) during 2 weeks of electrical stimulation of the gastrocnemius muscle attenuated $70 \%$ of stimulation-induced hypertrophy compared to the control condition. The same research group showed that electrical stimulation of rat gastrocnemius increased AR number by $25 \%$ within 3 days and the AR up-regulation preceded muscle hypertrophy. Deschenes et al. (48) showed RT in rats increased AR binding capacity in fast-twitch muscles (i.e., extensor digitorum longus) of rats but not slow-twitch (i.e., soleus). In humans, hypogonadism, aging, glucocorticoid use, obesity, and androgen deprivation therapy (ADT) are negative regulators of androgen actions. A study from Kvorning et al. (49) showed that 8 weeks of RT with or without the GnRH analog goserelin (that reduced TT to $\leq 2 \mathrm{nmol} / \mathrm{L}$ ) significantly attenuated increases in isometric strength and leg lean tissue mass. The authors concluded that suppression of $\mathrm{T}$ below $10 \%$ of normal levels strongly attenuates the increase in lean tissue mass and muscle strength seen during RT (49).

\section{ANDROGEN RECEPTOR PHYSIOLOGY}

The signaling effects of androgens are mediated through the AR which belongs to a family of steroid receptors. The AR gene is located on the $\mathrm{q}$ arm of chromosome $\mathrm{X}$ at position 11-12 and contains 8 exons that code for approximately 2,757 base pair open reading frames $(50,51)$. The first exon codes for the $\mathrm{N}$ terminus transcription activation domain; exons $2-3$ code for the central DNA binding domain; exons $4-8$ code for the $\mathrm{C}$ terminus ligand-binding domain (50). The AR consists of $\sim 920$ amino acids $(\sim 110 \mathrm{kD}$ or more when phosphorylated; and consists of 12 $\alpha$-helices and $2 \beta$-sheets) and is found in nearly all tissues in the human body and other truncated versions with biological activity have been identified (52). The presence of ARs correlates highly with the functions of androgens. AR activity may be altered by phosphorylation at several serine (and threonine and tyrosine) residues particularly in the transcription region (e.g., Ser81, $94,213,515,651)$, and through methylation, ubiquitination, sumoylation, and acetylation at various sites ( $>23$ sites). For example, phosphorylation of serine residue 651 is needed for full transcriptional activity (53). Phosphorylation may occur during ligand binding and through other signaling pathways indicating that the $\mathrm{AR}$ is cross-regulated by other ligandreceptor interactions (54). Thus, phosphorylation may augment androgen/AR transcriptional action (in the presence or absence of androgens) and demonstrate the high intracellular regulatory potential of the AR (55). The AR is activated through ligandindependent mechanisms including IGF-I induced MAPKERK1/2, p38, and JNK phosphorylation in $\mathrm{C}_{2} \mathrm{C}_{12}$ muscle cells (56). The AR may modulate its phosphorylation state to sensitize itself to anabolic signals in the presence of lower androgens. A recent study from Nicoll et al. (57) showed that men have higher baseline AR protein content than women; however, women had greater AR phosphorylation at rest at ser515 and ser81 residues indicating that the AR activity could be augmented independent of ligand levels.

\section{ANDROGEN RECEPTOR BINDING, STABILIZATION, AND TRANSCRIPTION}

Ligand binding occurs at the $\mathrm{C}$ terminus of the AR. Upon androgen binding to the ligand binding domain (LBD), dissociation from the heat-shock proteins occurs, hyperphosphorylation, dimerization, and conformational changes occur converting the AR to a transcription factor that interacts with androgen response elements or AREs of DNA (58). The AR DNA binding domain contains zinc finger motifs that recognize both consensus and selective AREs. Androgen binding activates and stabilizes the $A R$ and induces $\mathrm{N} \rightarrow \mathrm{C}$ terminus interaction which is selectively induced by high-affinity $\mathrm{T}$ and DHT, and lower-affinity anabolic steroids (e.g., oxandrolone, fluoxymesterone) (59). Greater stabilization is seen with DHT more so than $\mathrm{T}$ as $\mathrm{T}$ dissociates from the AR 3 times faster than DHT (60). Testosterone is the primary androgen interacting with ARs in skeletal muscle. Androgens have different potencies, in part, due to affinity and binding properties of the AR.

The androgen/AR complex serves as a transcription factor leading to increased protein synthesis. The $\mathrm{N}$-terminal domain is responsible for transcription activation. Androgen binding to the AR completes the groove that serves as a recruiting surface for co-activators (attract co-regulator motifs, e.g., LxxLL, FxxLF) that form a bridge between the DNA-bound AR and the transcriptional machinery. Co-regulator proteins mostly interact with the $\mathrm{N}$-terminus domain (with some binding at the LBD). More than 250 co-regulators exist many of which are co-activators (61). Co-activators augment transcriptional activity and enhance signaling, e.g., SRC-1, SRC-3, TIF-2, ARA24, ARA160, BAF57, BAF60A, ARA54, ARA70 whereas corepressors (e.g., SMRT, SIRT1, Ankrd1) reduce transcriptional activity. Many co-activators involve chromatin remodeling, 
histone acetyltransferase, methyltansferse, and demethylase, DNA stabilization, and pre-initiation complex (PIC) recruitment whereas some corepressors tighten nucleosomes limiting accessibility (61). Micro RNAs have been shown to mediate AR function via co-repressor expression inhibition (62). The AR LBD coactivator binding groove is a target of drugs to manipulate AR activity especially in the development of anti-prostate cancer drugs (63). However, little is known regarding RT and potential up-regulation of co-activators which may serve as a great area of interest for future research.

Several models have been proposed to explain mechanism(s) involved in gene transcription including chromatin remodeling, direct binding of $\mathrm{AR}$ to proteins in the PIC such as transcription factors TFIIB (i.e., transcription factor IIB) and TFIIF (i.e., transcription factor IIF), and AR interactions with complexing proteins and/or co-regulators to enhance assembly of the PIC $(64,65)$. It appears that a multiple-step model that incorporates combinations of these models may be most accurate. Upon DNA binding and co-activator recruitment, the co-activators covalently modify targeted histone $\mathrm{N}$ termini to loosen the nucleosomal structure (via modifying the net charge) to facilitate transcription in the repressed chromatin (61). Transcriptional activation by AR ultimately requires the recruitment of RNA polymerase II to the promoter of target genes. The co-regulators, as well as the ligand-bound activation of AR, enhance assembly of and stabilize the PIC, which is the assembly of general transcription factors (64). Polymerase II recruitment is mediated through the assembly of the PIC, the first step of which is binding of TATA binding protein (TBP) near the transcriptional start site. TBP is part of a multi-protein binding complex with TFIID that induce bending of DNA, which brings the sequence of the TATA element closer to interact with general transcription factors and co-regulators. TFIIB binds directly to TBP and functions to recruit the TFIIF-polymerase II complex. TFIIF domains also serve in transcription initiation and elongation. ATPase, the kinase TFIIE, and helicase TFIIH are then recruited to polymerase II to facilitate DNA strand separation before transcription initiation.

\section{ANDROGEN RECEPTOR POLYMORPHISMS AND PERFORMANCE}

The first exon contains several regions of repetitive DNA sequences one of which is the CAG (polyglutamine) triplet repeat that begins at codon 58 and extends for $>21$ repeats. This length varies between 8 and 35 repeats $(18-24$ is most common). Another is a polyglycine (GGN) repeat in the transactivation region. Genetic polymorphisms yielding a variety of repeats are associated with a variety of conditions including male infertility, hypogonadism, prostate, and testicular cancer, bone disease, neurodegenerative, and cardiovascular disease (66). These could contribute, in part, to responder or non-responder status when examining training adaptations. Long CAG repeats may interfere with androgen actions whereas short repeats (CAG and GGN) are associated with increased AR protein expression and androgen action. However, contradictory results were shown where CAG repeat number was positively related, inversely related, or not related to lean body mass (LBM), T, or FT concentrations, and muscle strength in young and older men (67-70). Nielsen et al. (71) showed inverse relationships between CAG repeat number and thigh and trunk muscle size to where every reduction in repeats of 10 equaled an increase of muscle size by $4 \%$. Thus, performance phenotypes based on AR candidate gene polymorphisms remain unclear.

\section{ANDROGEN RECEPTOR UP-REGULATION AND ADAPTATIONS TO RESISTANCE TRAINING}

AR protein content is a critical variable in RT-induced androgenmediated skeletal muscle protein accretion in healthy men (31). The concentration of ARs in skeletal muscle depends on the muscle fiber type, sex, training status, and androgen concentrations. Several studies investigated AR responses to RT (Table 1). Most studies show baseline AR protein content does not change although one study found significant downregulation (85) and one study reported up-regulation in older men (30). The most expected pattern of change is acute upregulation of AR mRNA and protein content within 1-2 days of RT followed by a return to baseline unless another workout is performed. Initially, AR protein content may not change or be down-regulated within the first $2 \mathrm{~h} \mathrm{PE}$ in the fasted state (73). Post-workout protein/CHO feeding may ameliorate this response (77). Notable up-regulation of AR mRNA and protein is seen $\sim 28 \mathrm{~h}$ PE (89) while is most pronounced $48 \mathrm{~h} \mathrm{PE}(74,75)$. The response is similar in young and old men (80) and may lessen over time with training experience (81). The AR mRNA and protein up-regulation correlated to TT and FT concentrations in the blood $(19,79)$. AR protein content explains a large amount of variance in muscle hypertrophy seen during RT (84), and its role may be potentiated with interaction of other hormones such as growth hormone and IGF-I.

\section{GROWTH HORMONE: A NEW COMPLEXITY WITH EXERCISE STRESS}

The concept that a "hormone" caused growth was first proposed in 1911 (90). Since that time, and as noted on PubMed, $>126,000$ publications have reported on some feature of growth hormone $(\mathrm{GH})$. Of that large number, comparatively few $(\sim 2,800)$ address its role in human exercise. In turn, only a small subset of these exercise studies considered the issue and importance of GH assay choice employed and the large difference it can make in interpreting experimental data. The purpose of this review is to (a) briefly review early history of GH bioassays, (b) summarize the data base that addresses the relevance of assay choice in performing exercise stress studies in humans, and (c) suggest how emerging data concerning GH processing in the pituitary gland may offer new direction(s) for the study of this anabolic hormone in health and aging. 
TABLE 1 | Summary of androgen receptor changes following resistance training.

\begin{tabular}{|c|c|c|c|c|c|}
\hline References & Subjects & Muscle & Protocol & $\begin{array}{l}\text { Biopsy } \\
\text { time }\end{array}$ & Results \\
\hline Kadi et al. (72) & $\begin{array}{l}\text { UT men, PL on AAS, } \\
\text { PL-no AAS }\end{array}$ & VL, TR & Cross-sectional comparison & $\mathrm{BL}$ & $\begin{array}{l}\mathrm{PL}>\% \text { AR-positive myonuclei in TR than UT } \\
-\mathrm{P}(\mathrm{AAS})>\% \text { AR-positive myonuclei than } \\
\text { drug-free } \mathrm{PL} \\
-\leftrightarrow \text { in } \mathrm{VL} \text { between groups }\end{array}$ \\
\hline $\begin{array}{l}\text { Ratamess et al. } \\
\text { (73) }\end{array}$ & RT men-fasted & $\mathrm{VL}$ & $\begin{array}{l}\text { SQ: } 1 \text { or } 6 \text { sets of } 10 \text { reps, } 80-85 \% \\
1 \mathrm{RM}-2-\text { min } \mathrm{RI}\end{array}$ & $1 \mathrm{~h} P E$ & $\begin{array}{l}1 \text { set }=\text { no change AR protein } 6 \text { sets }=\text { sig. } \downarrow \\
\text { AR protein } \\
- \text { BL AR content correlated with } 1 \mathrm{RM} \\
\text { squat strength }\end{array}$ \\
\hline Bamman et al. (74) & UT men and women & $\mathrm{VL}$ & $\begin{array}{l}\text { SQ: } 8 \times 8 \text { ECC reps }(\sim 110 \% 1 \mathrm{RM}) \text { or } \\
\text { CON reps ( } 85 \% 1 \mathrm{RM})\end{array}$ & 48h PE & AR mRNA $\uparrow$ by $102 \%$ (CON) and 63\% (ECC) \\
\hline $\begin{array}{l}\text { Willoughby and } \\
\text { Taylor (75) }\end{array}$ & UT men & VL & $\begin{array}{l}\text { SQ, LP, KE-3 sets of } 8-10 \text { reps each }-75 \\
\text { to } 80 \% 1 \mathrm{RM}, 3 \mathrm{~min} \mathrm{RI} \\
-3 \text { sessions separated by } 48 \mathrm{~h}\end{array}$ & 48h PE & $\begin{array}{l}\text { AR } m R N A \uparrow 35,68,43 \% \text { after each workout } \\
\text { AR protein } \uparrow 40,100,202 \% \text { after each workout } \\
\text { - AR mRNA/protein correlated with PE TT } \\
\text { and FT }\end{array}$ \\
\hline Vingren et al. (76) & $\begin{array}{l}\text { RT men and } \\
\text { women - fasted }\end{array}$ & $\mathrm{VL}$ & SQ: 6 × 10 reps $-80 \%$ 1RM, 2-min RI & $\begin{array}{l}10 \text { and } \\
70 \text { min } \\
\text { PE }\end{array}$ & $\begin{array}{l}\text { AR protein } \downarrow \text { at } 10 \text { min in women; } \downarrow \text { at } 70 \text { min in } \\
\text { men and women } \\
- \text { AR protein men }>\text { women }\end{array}$ \\
\hline Kraemer et al. (77) & RT men & $\mathrm{VL}$ & $\begin{array}{l}\text { SQ, BP, BOR, SP: } 4 \times 10 \text { reps each } 80 \% \\
1 \mathrm{RM}, 2 \text {-min RI } \\
- \text { Water }+ \text { L-carnitine or feeding }+ \\
\text { L-carnitine post RE }\end{array}$ & $1 \mathrm{~h} P \mathrm{PE}$ & Feeding $\uparrow A R$ protein \\
\hline Spiering et al. (25) & UT men-fasted & $\mathrm{VL}$ & $\begin{array}{l}5 \times 5 R M \text { KE following rest (CON) or after } \\
\text { upper body RE eliciting } T T \uparrow \text { by } 16 \%(H T)\end{array}$ & $\begin{array}{l}10 \text { and } \\
180 \text { min } \\
\text { PE }\end{array}$ & $\begin{array}{l}\text { AR protein at } 180 \text { min tended to } \downarrow \text { in } \mathrm{CON}, \leftrightarrow \text { in } \\
\mathrm{HT} \text { from REST; AR protein following } \mathrm{HT}>\mathrm{CON}\end{array}$ \\
\hline West et al. (78) & $\begin{array}{l}\text { MT men and } \\
\text { women-fed PE }\end{array}$ & $\mathrm{VL}$ & $\begin{array}{l}\text { LP }-5 \times 10 \text { reps; leg ext/curl superset } 3 \times \\
12 \text { reps, } 1 \text { min RI }\end{array}$ & $\begin{array}{l}1,5,26 \\
28 \text { h PE }\end{array}$ & $\begin{array}{l}\leftrightarrow \mathrm{AR} m \mathrm{mRNA} \text { at } 1,5 \mathrm{~h} \\
\mathrm{AR} \mathrm{mRNA} \uparrow 28 \mathrm{~h}>26 \mathrm{~h}\end{array}$ \\
\hline Poole et al. (19) & $\begin{array}{l}\text { UT young and older } \\
\text { (60-75 years) men }\end{array}$ & VL & $\begin{array}{l}9 \text { sets of lower-body RE, } 10 \text { reps each set, } \\
80 \% \text { of } 1 \mathrm{RM}, 2-3 \mathrm{~min} \mathrm{RI}-\text { completed } 3 \\
\text { workouts }\end{array}$ & $\begin{array}{l}24,48 h \\
P E\end{array}$ & $\begin{array}{l}\leftrightarrow \text { AR mRNA } 48 \text { or } 24 \mathrm{~h} \text { post RE over } 3 \text { days } \\
\text { AR mRNA young men > old } \\
- \text { PE TT at } 30 \text { min correlated to AR mRNA }\end{array}$ \\
\hline Hulmi et al. (79) & $\begin{array}{l}\text { RT older ( } 57-72 \text { years) } \\
\text { men }\end{array}$ & $\mathrm{VL}$ & Whey or placebo: LP-5 × 10RM, 2-min RI & $\begin{array}{l}1 \text { and } \\
48 \mathrm{~h} P E\end{array}$ & $\begin{array}{l}\text { AR mRNA trend for } \uparrow \text { in whey group; when } \\
\text { groups combined sig. } \uparrow \text { in AR mRNA } 1 \text { and } \\
48 \mathrm{~h} \\
\text { Trend for } \uparrow \mathrm{AR} \text { protein in placebo } 1 \mathrm{~h} \\
- \text { Change in AR mRNA } 1 \mathrm{~h} \text { correlated to PE } \\
\text { TT response }\end{array}$ \\
\hline Ahtiainen et al. (80) & $\begin{array}{l}\text { UT young and older } \\
\text { (60-65 years) men }\end{array}$ & $\mathrm{VL}$ & $\begin{array}{l}\text { Acute RE before } \& \text { after } 21 \text { weeks of RT: } \\
\text { protocol-LP }-5 \times 10 \mathrm{RM}, 2 \mathrm{~min} \mathrm{Rl}\end{array}$ & $\begin{array}{l}1 \text { and } \\
48 \mathrm{~h} \mathrm{PE}\end{array}$ & $\begin{array}{l}\leftrightarrow \text { Acute AR protein and mRNA response over } \\
21 \text { weeks } \\
- \text { AR response correlated to } 1 \text { RM strength, } \\
\text { LBM, and CSA } \\
-\leftrightarrow B L A R \text { mRNA/protein between old \& } \\
\text { young men or after RT }\end{array}$ \\
\hline Ahtiainen et al. (81) & RT young men & $\mathrm{VL}$ & $\mathrm{LP}-5 \times 10 \mathrm{RM}, \mathrm{SQ}-4 \times 10 \mathrm{RM}, 2 \mathrm{~min} \mathrm{Rl}$ & $\begin{array}{l}1 \text { and } \\
48 \mathrm{~h} \mathrm{PE}\end{array}$ & $\leftrightarrow \mathrm{AR}$ mRNA and protein \\
\hline Ahtiainen et al. (82) & $\begin{array}{l}\text { UT young and older } \\
\text { (70-75 years) men }\end{array}$ & VL & $\begin{array}{l}\text { Acute RE before and after } 12 \text { months of } \\
\text { lower-body RT: protocol-LP }-5 \times 10 R M \text {, } \\
\text { 2-min Rl }\end{array}$ & $\begin{array}{l}\mathrm{IP}(0) \text { and } \\
2 \mathrm{hPE}\end{array}$ & $\begin{array}{l}\leftrightarrow \mathrm{AR} \text { content } \mathrm{O} \text { and } 2 \mathrm{~h} \\
\text { Chronic: } \leftrightarrow \mathrm{BL} \text { VL } \mathrm{AR} \text { content } \\
\text { - No difference between } \mathrm{BL} V L \mathrm{AR} \text { content in } \\
\text { young and old men }\end{array}$ \\
\hline Kvorning et al. (27) & $\begin{array}{l}\text { Young men, limited RT } \\
\text { experience }\end{array}$ & $\mathrm{VL}$ & $\begin{array}{l}8 \text { weeks of RT: GnRH analog (goserelin, } \\
3.6 \mathrm{mg} 3 \text { times to } \downarrow T \text { ) or placebo; acute } \\
\text { RE pre and post RT }\end{array}$ & $\begin{array}{l}\text { BL, 4, } \\
24 \mathrm{~h} \mathrm{PE}\end{array}$ & $\begin{array}{l}\text { Blocked } T \text { and } R T \text { had no effect on } A R \text { mRNA } \\
\text { acute or chronic at } B L\end{array}$ \\
\hline Nilsen et al. (83) & $\begin{array}{l}\text { Men with prostate } \\
\text { cancer on ADT }\end{array}$ & $\mathrm{VL}$ & 16 weeks of RT & $\mathrm{BL}$ & $\leftrightarrow \mathrm{BL}$ AR protein content \\
\hline Sato et al. (30) & $\begin{array}{l}\text { UT young and older } \\
\text { (mean }=67 \text { years) men }\end{array}$ & $\mathrm{VL}$ & $\begin{array}{l}12 \text { weeks of RT: } 3 \text { days/week, KE and } \\
\text { LC-3 } 310 \text { reps, } 70 \% \text { of } 1 \mathrm{RM}, 3-\mathrm{min} \mathrm{RI}\end{array}$ & $\mathrm{BL}$ & $\begin{array}{l}\text { AR protein in young men > old men } \\
- \text { BL AR protein } \uparrow \text { in old men (no post biopsies } \\
\text { taken for young men) }\end{array}$ \\
\hline Morton et al. (31) & Young RT men & $\mathrm{VL}$ & $\begin{array}{l}12 \text { weeks of RT: high reps ( } 20-25 \text { reps } \\
\text { with } 30-50 \% \text { of } 1 \mathrm{RM} \text { ) or low reps (8-12 } \\
\text { reps with } 75-90 \% \text { of } 1 \mathrm{RM})\end{array}$ & $B L$ & $\begin{array}{l}\leftrightarrow \mathrm{BL} \text { AR protein content over } 12 \text { weeks } \\
- \text { AR protein content in responders }> \\
\text { non-responders }\end{array}$ \\
\hline
\end{tabular}


TABLE 1 | Continued

\begin{tabular}{|c|c|c|c|c|c|}
\hline References & Subjects & Muscle & Protocol & $\begin{array}{l}\text { Biopsy } \\
\text { Time }\end{array}$ & Results \\
\hline & & & $\begin{array}{l}\text { - Divided subjects into responders } \\
\text { vs. non-responders }\end{array}$ & & $\begin{array}{l}\text { - AR protein content correlated with LBM, } \\
\text { type I, and type II muscle CSA }\end{array}$ \\
\hline Mitchell et al. (84) & UT young men & $\mathrm{VL}$ & $\begin{array}{l}16 \text { weeks of RT: } 4 \times / \text { wk- upper/lower } \\
\text { body split: } 3 \times 6-12 \text { reps, } 1-2 \text { min RI }\end{array}$ & $\mathrm{BL}$ & $\begin{array}{l}\leftrightarrow \mathrm{BL} \text { AR protein content } \\
-\Delta \mathrm{AR} \text { protein correlated to fiber CSA } \\
-\mathrm{AR} \text { protein \& } \mathrm{p} 70 \mathrm{~S} 6 \mathrm{~K} \text { phosphorylation } \\
\text { accounted for } 46 \% \text { of variance in size }\end{array}$ \\
\hline Mobley et al. (85) & UT young men & VL & $\begin{array}{l}12 \text { weeks of RT: } 3 \text { days/week, } 5 \text { exercises } \\
\text { - undulating periodization, } 4-10 \text { reps }\end{array}$ & $\mathrm{BL}$ & $\begin{array}{l}\downarrow \mathrm{BL} \text { AR protein content similar in low, } \\
\text { moderate, and high responders }\end{array}$ \\
\hline Haun et al. (86) & $\begin{array}{l}\text { Young previously RT } \\
\text { men }\end{array}$ & $\mathrm{VL}$ & $\begin{array}{l}6 \text { weeks of RT: } 3 \text { days/week, } 10 \text { reps } \\
\text { per set, } 60 \% \text { of } 1 \mathrm{RM}, 10-32 \text { sets per } \\
\text { exercise per week }\end{array}$ & $\mathrm{BL}$ & $\begin{array}{l}\leftrightarrow \mathrm{BL} \text { AR protein content in high and low } \\
\text { responders }\end{array}$ \\
\hline Roberts et al. (87) & $\begin{array}{l}\text { UT young and older } \\
\text { (mean }=68 \text { years) men }\end{array}$ & $\mathrm{VL}$ & $\begin{array}{l}\text { Acute RE: SQ, LP, KE } \\
-3 \times 10 \text { reps, } 80 \% \text { of } 1 \mathrm{RM}, 3 \mathrm{~min} \mathrm{Rl}\end{array}$ & $24 \mathrm{~h} \mathrm{PE}$ & $\begin{array}{l}\text { BL AR mRNA in older men > young } \\
-\leftrightarrow \text { AR mRNA } 24 \mathrm{hrs} \text { PE in either group } \\
- \text { FT negatively correlated with AR mRNA }\end{array}$ \\
\hline Brook et al. (88) & $\begin{array}{l}\text { UT young and older } \\
\text { ( 69 yrs) men }\end{array}$ & $\mathrm{VL}$ & $\begin{array}{l}6 \text { weeks of RT: unilateral KE, } 6 \times 8 \text { reps } \\
75 \% \text { of } 1 \mathrm{RM}\end{array}$ & $\begin{array}{l}\text { BL, } \\
90 \text { min } \\
\text { PE }\end{array}$ & $\begin{array}{l}\leftrightarrow \mathrm{BL} \text { AR mRNA } \\
\leftrightarrow \mathrm{PE} \mathrm{AR} \mathrm{mRNA}\end{array}$ \\
\hline
\end{tabular}

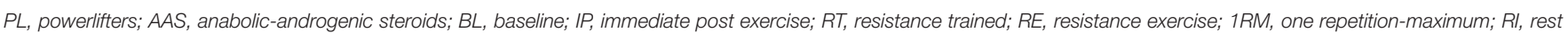

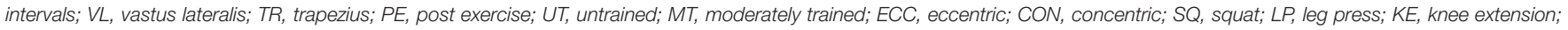

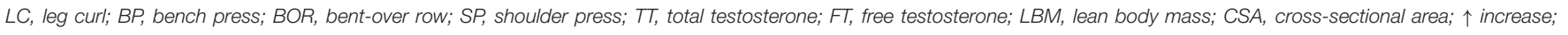
$\downarrow$ decrease; $\leftrightarrow$ no change.

\section{EARLY HISTORY OF GH BIOASSAY}

The isolation of GH from pituitary extracts of many mammalian species, using biochemical techniques available at that time [ 1950's-1970's], was described in a review by Papkoff and Li (91). During this early period, the three most often used growth bioassays were (a) the weight gain assay in the plateaued female rat; (b) the weight gain assay in the immature hypophysectomized rat; and (c) the tibia test; an assay originally proposed by Greenspan et al. (92) that measured bone growth at the tibial plate of the hypophysectomized rat following a 4 day injection of GH test sample. In addition, investigators also used other types of biological assays to measure circulating $\mathrm{GH}$ hormone that had other endpoints (e.g., lipolysis, carbohydrate metabolism). In fact, results from such differing assay approaches led C.H. Li to propose that a better name for the hormone might be "metabolic hormone" (93). To the best of our knowledge, it was also during this time period (1965) that the first study documenting that human exercise was a potent stimulus for the release of GH from the pituitary appeared (94).

A 15 year period $(\sim 1970-1985)$ marks the time when a majority of clinical and basic investigators appear to have transitioned from measuring circulating GH by biological assay to immunoassay. During this transition period, a critically important experimental series by Ellis et al. (95) was designed to compare results generated between rat growth assays and GH immunoassays. Their data unequivocally showed that bioassays and immunological assay results did not correlate. Plasma GH concentrations measured by this in vivo bioassay were estimated to be much greater $(\sim 300 \mathrm{x})$ than those measured by immunoassay. Further, in 1978 this group reported that a pituitary growth factor, which escaped detection by immunoassay, nevertheless had strong GH activity in the established rat tibia bioassay (95). Their biochemical studies indicated that this factor was relatively large $(\sim 80 \mathrm{kDa})$. Moreover, the relative concentrations of bioactive GH in the rat pituitary and/or circulation (including human plasma) changed differentially in response to a variety of physiological stimuli (e.g., cold stress, fasting, insulin injection). This study was largely ignored. In retrospect, the authors of this review believe that this pioneering study should have had a more significant impact on future GH research efforts than it did. The ramifications of this concept for the multi-dimensionality of the many GH isoforms are further delineated in a recent review (96).

\section{GH ISOFORMS}

A comprehensive review of $\mathrm{GH}$ variants, their isolation, availability, and physiological activities is beyond the scope of this review. However, the following points help establish the thesis of this review, viz. that other potent hGH bioactive forms are present in the pituitary and plasma. However, many remain to be fully characterized, both physiologically and structurally. It is clear: $\mathrm{GH}$ is not a single substance.

After gene cloning, the first recombinant human GH (rhGH) was produced biosynthetically in 1979 by Genentech (San Francisco, California). Work on this product showed that the 191 amino acid isoform $(22 \mathrm{kDa})$ was identical to a native molecule present in the pituitary gland and plasma (97). This form was active in the tibial bioassay as well as other bioassays having the growth endpoint. Two factors; viz. (a) availability of the recombinant product and (b) closure of the National Pituitary Agency (in 1985) for production of hGH extracted from human 
pituitary glands, led to overwhelming use of antibody- based technology (e.g., polyclonal, monoclonal antibodies) and less frequently used cell- based bioassays for GH measurements.

In the $\sim 30$ years following the Ellis report, pioneering biochemical experiments from many laboratories (Lewis, Sinha, Kostyo, and Baumann to name but a few) led to the now familiar realization, summarized by Baumann (98) that ..."human growth hormone is a heterogeneous protein, consisting of several isoforms" and that.. "sources of this heterogeneity reside at the level of the genome, mRNA splicing, post-translation modification, and metabolism." According to Baumann (98), and especially relevant to this review, we point out that $\sim 50 \%$ of hGH isoforms in human blood 15-30 min after a secretory pulse are classified as the $22 \mathrm{kDa}$ monomeric form (half bound to $\mathrm{GH}$ binding protein). Oligomeric and aggregated forms are believed to make up a significant portion of the remaining isoforms. Baumann concluded, in 2009 (98), what is true today; viz. that the biological significance of such isoform heterogeneity remains largely unknown. Earlier attempts to purify $\mathrm{GH}$ variants (between 1975 and 2000) were directed at understanding their physiological effects; however definitive conclusions relating to their bioactivity remained largely unknown. A review by U. J. Lewis (99) entitled "GH: What is it and what does it do?" makes the point another way. The abstract is provocative and relevant for this review .... "The evidence is now irrefutable that growth hormone (GH), long thought to be a single substance, is actually a mixture of several different forms. These multiple forms must be a consideration in any physiologic study if an accurate evaluation of the actions of GH is to be made" (99).

Fragmentation of the native $22 \mathrm{kDa}$ hormone into two peptides [hGH 1-43] and [hGH 44-191] may affect physiology; the shorter fragment has insulin potentiating activity while the larger has anti-insulin activities, thereby implying that the native molecule acts as a prohormone (99). Similarly, exposure of GH to serine proteases will enhance activity of the hormone at the tibial plate (100). If GH has so many metabolic activities, is their mechanism of action via a common receptor? Lewis addresses this point in a 1996 report: "currently it is believed that all of these actions are mediated through the cloned GH receptor, but this is not proven" (101). To the best of our knowledge that is true to this day.

\section{INTEREST IN HUMAN EXERCISE, BIOACTIVE, AND IMMUNO-REACTIVE GH, RE-AWAKENS}

Some 20 years after the original report by Ellis et al. (95), pioneering research by Reggie Edgerton, Gary McCall, and Richard Grindeland (at UCLA/NASA Ames) offered evidence for the existence of neural afferent inputs from skeletal muscle that modulated secretion of hGH measured by tibial bioassay. Three trials done between 1995 and 2001 are described in a 2001 review by McCall et al. (102-105). Their designs included: complete bed rest (17 days); astronaut exposure during and after microgravity; and vibration-induced activation of muscle afferents. The exercise component in these trials was either repeated bouts of ankle dorsiflexion or muscle unloading. The interesting findings were that plasma concentrations of bioactive $\mathrm{GH}$ changed dramatically, but concentrations of immunoreactive $\mathrm{GH}$ were not affected by treatment. These findings clearly challenged the concept that a single molecular form of the hormone is responsible for the growth response (103-105). How activation of a small muscle group, and the neural paths taken, lead to this GH response remains largely unexplored.

How the more standard resistance exercise protocols affected plasma $\mathrm{GH}$, when measured by bioassay and an array of immunoassays, were reported by the Kraemer group between 2001 and 2014. The 2001 study, Hymer et al. (106) was an acute pre-post exercise trial [six sets of 10 at $75 \%$ of the 1 repetition maximum (1RM)] involving 35 young (23 year) females tested during the follicular phase of the menstrual cycle. As expected, plasma concentrations of $\mathrm{GH}$, measured by polyclonal, monoclonal radioimmunoassay, and immunofunctional assay [the latter based upon epitope binding of the $\mathrm{GH}$ isoform (107), increased after the exercise bout. However, plasma concentrations of GH measured by tibial assay were not different than control samples (Table 2)]. Fractionation of these plasma samples by size exclusion chromatography showed that treatment-induced increases in immunoactive $\mathrm{GH}$ was associated with molecular forms in mass ranges expected for dimeric (30-60 $\mathrm{kDa})$ and monomeric $(<30 \mathrm{kDa}) \mathrm{GH}$.

From the results of this initial 2001 study (106), which involved untrained women, it was clear that the pituitary failed to respond to the exercise stress by secreting additional biologically active GH. To address the question of possible importance of exercise training, Kraemer et al. (111) undertook an extensive 6 month training program using different combinations of resistance training (i.e., either total body or upper body) using a progressive linear periodized training program supplemented by standard endurance training. As expected, each of the training groups experienced significant gains in the strength of the involved musculature over the training period, thus lending internal validity to the training study. Plasma samples were obtained both pre- to post- resistance exercise and pre- and posttraining. With training, and as expected, iGH concentrations increased even further and highest assay signals were recorded using monoclonal antibody. bGH concentrations in both unfractionated and fractionated plasma samples were variable with four different training groups (two total body training groups presented in Table 2), In this same trial, GH assays of form(s) contained in three molecular weight classes, prepared by size exclusion chromatography, yielded equally interesting results. Thus, smaller $(30 \mathrm{kDa})$ molecular mass variants generated the largest immunoreactive responses; however, larger ( $>60 \mathrm{kDa})$ molecular mass variants contained form(s) that were equally as potent as the small $(30 \mathrm{kDa})$ and medium $(30-60 \mathrm{kDa})$ class fractions in terms of generating a bone growth response. We believe this interesting result reflects the importance of either disulfide linked GH aggregates, and/or GH bound to GH-binding protein, for generation of somatogenic activity.

But most important exercise-induced changes in $\mathrm{GH}$ bioactivity were experienced after 6 months of training $(6 \times 10$ squat at $80 \%$ of $1 \mathrm{RM}$ with 2 min rest between sets).

a. The total body strength training group demonstrated in the unfractionated total a significant elevation in resting $\mathrm{bGH}$, 


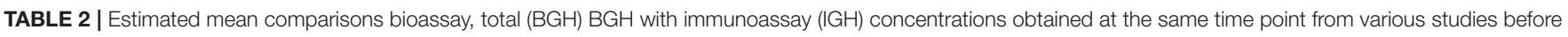
and after resistance exercise (highest value), and analyses.

\begin{tabular}{|c|c|c|c|c|c|c|c|c|c|c|c|c|}
\hline \multicolumn{2}{|c|}{ IGH $\left(\mu \mathrm{g} \bullet L^{-1}\right)$} & \multicolumn{2}{|c|}{ BGH $\left(\mu \mathrm{g} \bullet \mathrm{L}^{-1}\right)$} & \multicolumn{6}{|c|}{ IGH $\left(\mu g \bullet L^{-1}\right)$ and BGH $\left(\mu g \bullet L^{-1}\right)$ fractions } & \multirow[b]{2}{*}{ Gender } & \multirow[b]{2}{*}{$\begin{array}{c}\text { Age } \pm \text { SD } \\
(y r s)\end{array}$} & \multirow[b]{2}{*}{ References } \\
\hline Rest & Post-ex & Rest & Post-ex & $\begin{aligned} \leq & 30 \mathrm{kD} \\
& \text { rest }\end{aligned}$ & $\begin{array}{l}\leq 30 \text { kD } \\
\text { Post -ex }\end{array}$ & $\begin{array}{l}30-60 \mathrm{kD} \\
\text { rest }\end{array}$ & $\begin{array}{c}30-60 \\
\text { kD Post-ex }\end{array}$ & $\begin{aligned} \geq & 60 \mathrm{kD} \\
& \text { rest }\end{aligned}$ & $\begin{array}{l}\geq 60 \mathrm{kD} \\
\text { Post-ex }\end{array}$ & & & \\
\hline 1.1 & 1.2 & 3,800 & $10,000^{\star}$ & & & & & & & Male & $43.8 \pm 63.8$ & McCall et al. (103) \\
\hline Nichols & & & & Nichols(IGH) & & & & & & Female & $23 \pm 6.4$ & Hymer et al. (106) \\
\hline 2.5 & $9.5^{\star}$ & & & 2.5 & $7.4^{\star}$ & 2.0 & $7.5^{\star}$ & 0.5 & 1.5 & & & \\
\hline NIDDK & & & & NIDDK(IGH) & & & & & & & & \\
\hline \multirow[t]{3}{*}{1.0} & $2.5^{\star}$ & & & 2.5 & $10.5^{\star}$ & 1 & $4.0^{\star}$ & 0.5 & 1.0 & & & \\
\hline & & & & $\mathrm{BGH}$ & & & & & & & & \\
\hline & & 2,200 & 2,000 & 1,200 & 1,000 & 1,480 & 1,395 & 1,400 & 1,490 & & & \\
\hline 4.1 & $9.5^{\star}$ & 1,650 & 2,400 & & & & & & & Female & $23.0 \pm 1.2$ & Kraemer et al. (108) \\
\hline Pre-training & & & & & & & & & & Female & $23 \pm 3$ & Kraemer et al. (77) \\
\hline NIDDK & & & & $\mathrm{IGH}$ & & & & & & & & Total-Strength Group \\
\hline 2.0 & $3.1^{*}$ & & & 2.0 & $8.2^{*}$ & 1.8 & $4.8^{\star}$ & 0.2 & 0.8 & & & \\
\hline \multicolumn{13}{|l|}{ Nichols } \\
\hline \multirow[t]{3}{*}{2.5} & $11.3^{*}$ & & & 3.1 & $8.0^{\star}$ & 3.0 & $9.1^{\star}$ & 1.0 & $2.0^{*}$ & & & \\
\hline & & & & $\mathrm{BGH}$ & & & & & & & & \\
\hline & & 2,450 & 3,150 & 1,500 & $650^{*}$ & 990 & 750 & 1,400 & 4,150 & & & \\
\hline \multicolumn{13}{|l|}{ Post-training } \\
\hline NIDDK & & & & $\mathrm{IGH}$ & & & & & & & & \\
\hline 3.2 & $7.0^{\star}$ & & & 4.8 & $12.0^{\star \#}$ & 2.5 & $8.8^{\star \#}$ & 0.8 & 1.5 & & & \\
\hline \multicolumn{13}{|l|}{ Nichols } \\
\hline \multirow[t]{3}{*}{4.8} & $14.2^{*}$ & & & 2.0 & $6.1^{\star \#}$ & 2.5 & $10.0^{*}$ & 0.8 & 1.0 & & & \\
\hline & & & & $\mathrm{BGH}$ & & & & & & & & \\
\hline & & $3,850^{\#}$ & 3,450 & $1,250^{\#}$ & $1,500^{\#}$ & 1,250 & $1,250^{\#}$ & 1,150 & $2,450^{\star \#}$ & & & \\
\hline Pre-training & & & & & & & & & & Female & $26.3 \pm 4.0$ & Kraemer et al. (77) \\
\hline NIDDK & & & & IGH & & & & & & & & $\begin{array}{c}\text { Total-Hypertrophy } \\
\text { Group }\end{array}$ \\
\hline 1.8 & $2.5^{\star}$ & & & 2.6 & $8.0^{*}$ & 1.2 & $3.8^{*}$ & 0.1 & 0.8 & & & \\
\hline \multicolumn{13}{|l|}{ Nichols } \\
\hline \multirow[t]{3}{*}{2.7} & $8.0^{\star}$ & & & 2.7 & $8.2^{\star}$ & 1.6 & $7.2^{\star}$ & 0.3 & $2.0^{\star}$ & & & \\
\hline & & & & $\mathrm{BGH}$ & & & & & & & & \\
\hline & & 2,950 & $1,900^{\star}$ & 1,550 & 1,010 & 1,650 & 1,100 & 1,950 & 1,550 & & & \\
\hline \multicolumn{13}{|l|}{ Post-training } \\
\hline NIDDK & & & & $\mathrm{IGH}$ & & & & & & & & \\
\hline 1.8 & $4.5^{\star}$ & & & 2.4 & $7.0^{\star \#}$ & 2.0 & $4.8^{\star}$ & 0.2 & 0.8 & & & \\
\hline \multicolumn{13}{|l|}{ Nichols } \\
\hline \multirow[t]{4}{*}{1.9} & $13.1^{\star \#}$ & & & 1.1 & $5.0^{* \#}$ & 1.3 & $8.6^{\star \#}$ & 0.1 & $1.2^{*}$ & & & \\
\hline & & & & $\mathrm{BGH}$ & & & & & & & & \\
\hline & & 2,900 & $2,500^{\#}$ & 1,090 & 1,190 & $1,950^{\#}$ & $750^{\star}$ & 1,600 & $2,010^{\#}$ & & & \\
\hline & & & & $\%$ & $\%$ & $\%$ & & & & Female & $61.6 \pm 1.3$ & Gordon et al. (110) \\
\hline Old & & & & $\mathrm{IGH}$ & $\mathrm{IGH}$ & $\mathrm{IGH}$ & & & & & & Resistance Ex \\
\hline 2.5 & $4.8^{\star}$ & & 980 & 30 & 55 & 15 & & & & & & \\
\hline & & & & $\mathrm{BGH}$ & $\mathrm{BGH}$ & $\mathrm{BGH}$ & & & & & & \\
\hline & & & & 15 & 45 & 40 & & & & & & \\
\hline Young & & & & $\mathrm{IGH}$ & $\mathrm{IGH}$ & $\mathrm{IGH}$ & & & & & & \\
\hline 3.5 & $17.5^{\star}$ & & 1,725 & 40 & 40 & 20 & & & & & & \\
\hline & & & & $\mathrm{BGH}$ & $\mathrm{BGH}$ & $\mathrm{BGH}$ & & & & & & \\
\hline & & & & 30 & 40 & 30 & & & & & & \\
\hline 1.0 & $10.0^{\star}$ & 6,400 & 11,500 & & & & & & & Male & $20.1 \pm 2.1$ & Thomas et al. (109) \\
\hline 0.4 & $7.0^{\star}$ & 3,800 & 6,200 & & & & & & & Male & $21.0 \pm 2.1$ & Thomas et al. (109) \\
\hline 4.5 & $16.5^{\star}$ & & 1,740 & & & & & & & Female & $23.7 \pm 1.0$ & Gordon et al. (110) \\
\hline 0.6 & & 2360.9 & & & & & & & & Male & $80.5 \pm 1.6$ & Kraemer et al. (1) \\
\hline 2.0 & & 4966.1 & & & & & & & & Female & $80.7 \pm 1.4$ & Kraemer et al. (1) \\
\hline
\end{tabular}

*Significant increase from corresponding resting value.

\#Significant difference from pre-training. 
and with training in the $>60 \mathrm{kD}$ fraction showing uniquely an increase with acute exercise and this acute response was significantly higher post-training. Additionally, other fractions also demonstrated higher post training values. Thus, the bGH appeared for the first time to be responsive to exercise stress and also demonstrated adaptations to training in these young women. While not shown in Table 2 the upper body only strength training group also showed similar changes with significant increases in the unfractionated resting values as well as a significant exercise-induced response following training, again showing the influence of training on bGH.

b. In the total hypertrophy group, it was observed that pretraining acute exercise resulted in a significant decrease in the UF samples and this was observed again post-training yet the post-exercise values were significantly higher. Again, while not shown in the table, the upper body group showed no acute exercise changes in the UF samples pre-training but with training, resting values were significantly higher and a significant exercise-induced elevation was observed.

Taken together, these results indicated for the first time that acute and chronic exercise training using conventional large muscle group resistance training protocols will increase (acutely and chronically) plasma concentrations of GH bioactivity in young women. McCall had shown previously that exercise of small muscle groups would also increase plasma concentrations of bGH $(103,104)$.

Data from other studies also reveal the dichotomy between bioactive and immunoreactive GH. Comparison of bGH plasma levels from 24 vs. 62 year old female volunteers, after acute aerobic cycle exercise, were not different. However, after an additional acute resistance exercise bout, plasma concentrations of bGH from the younger group were significantly higher than those in the older group. These higher concentrations were associated with molecular forms of apparent mass $30-55 \mathrm{kDa}$ (i.e., dimer range) (110).

Comparison of bGH plasma concentrations from lean $[\mathrm{BMI}=$ $23]$ vs. obese $[\mathrm{BMI}=36]$ men revealed that although resistance exercise had no significant effect, their concentration in the leaner group was significantly higher. Similar to other studies, concentrations of $\mathrm{GH}$ measured by immunoassay were not different between the two groups (109).

A trial done with free-living 81 year old individuals, failed to uncover differences in plasma GH concentrations (measured by either bioassay or immunoassay) that could be correlated with either fitness or physical performance. Curiously, one half of the group ( $n=21)$ had plasma concentrations of bioactive GH that were essentially zero, while the other half $(n=20)$ had concentrations that were readily detectable and in the range of studies listed previously (112).

\section{HOW EXPERIMENTS WITH RATS OFFER CLUES RELEVANT TO HUMAN EXERCISE AND BIOACTIVE GH}

\section{Somatotroph Heterogeneity}

Cell separation studies indicate that two populations of GH cells (somatotrophs) are present, in roughly equal numbers ( $\sim 40 \%)$, in the rat pituitary gland. One population (light somatotrophs, also designated the type I cell) has densities $<1.071 \mathrm{~g} / \mathrm{cm}^{3}$, while the other (heavy somatotrophs, also designated the type II cell) has densities in ranges $>1.071-1.085 \mathrm{~g} / \mathrm{cm}^{3}$. The higher density of the type II cell is attributable to large numbers of $300 \mathrm{~nm}$ diameter, GH containing, cytoplasmic secretory granules. Results from a recent experiment (113), designed to determine if the $\mathrm{GH}$ released from light vs. heavy somatotrophs is differentially active by bioassay, offer definitive evidence to support the hypothesis that differential responses between bioassay vs. immunoassay results after human exercise (described previously), has a structural (cellular) basis residing within the pituitary gland itself. Results of this experiment showed that: (1) culture media from type II cells contained $5 \mathrm{x}$ as much bGH (tibial assay) as that from type I cells; (2) net production of bGH from type II cells was $6 \mathrm{x}$ more than that from type I cells $(p<0.001)$, but production of iGH was not different between type I vs. II cells; (3) implantation of type II cells into rat brain ventricles of hypophysectomized recipients significantly increased body weights, tibial widths and gastrocnemius muscle; however, implantation of type I cells had little to no significant effect on these same markers; and (4) type II cells prepared from animals that had been previously fasted or insulin injected showed markedly reduced bGH secretion. Recent studies using RNAseq assays also demonstrate somatotroph heterogeneity in mice, e.g., a subpopulation enriched in sterol/cholesterol synthesis genes (114). Additionally, another study using RNAseq assays also showed a subpopulation of somatotrophs demonstrating sex dependent differences in anterior pituitary cells in female rats (115), Thus, others have also found somatotroph heterogeneity using other molecular techniques harking back historically to some of the first observations of this phenomenon $(116,117)$.

\section{The GH Secretory Granule}

These membrane bound cytoplasmic organelles contain $\sim 75 \%$ of the total bioactive hormone measured in the pituitary homogenate (118). The hormone in the granule is bound cooperatively with two $\mathrm{Zn}$ (II) ions per GH dimer (119). Each granule is estimated to contain 5,000-10,000 molecules and its dense core consists of large, crystal-like aggregates which are thought to solubilize on exocytosis (120-122). Some GH granules contain cytochrome $\mathrm{C}$, cytochrome oxidase and ATP; molecules that may mediate $\mathrm{GH}$ release (121).

On electrophoresis in non-reducing SDS gels, rat pituitary extracts contain a wide range of di-sulfide linked $\mathrm{GH}$ variants (14-88 kDa MW) (123). Electro-elution of protein from different regions of such gels, followed by their chemical reduction, apparently uncovers epitopes hidden in the aggregate, thereby increasing iGH activity up to $6 \mathrm{X}$. Oligomeric forms $>44 \mathrm{kDa}$ are found exclusively in extracts prepared from dense, highly granulated, purified type II- bGH producing- somatotrophs (pentamers). Extracts from the less dense, less granulated, type I somatotrophs contain a single dominant $22 \mathrm{kDa}$ peak and a minor $44 \mathrm{kDa}$ species (dimer). Chemical reduction of culture media from type II, but not type I, somatotrophs increases immunoreactivity ( $5 \mathrm{X}$ vs. $1.3 \mathrm{X}$, respectively). This important result confirmed maintenance of granule heterogeneity within the somatotroph in cell culture. Since GH released from the type 
II somatotroph, relative to type I cells, is most active in both in vitro (cell culture) and in vivo (hollow fiber implant) bGH tests, the results of Farrington and Hymer (123) and Grindeland et al. (113), support the contention that bGH activity is associated with disulfide linked aggregates (oligomers) residing in granules of the type II somatotroph, as well as bGH activity in culture media secreted from the type II somatotroph.

\section{Growth Hormone Is Stored as an Amyloid}

A major advance in understanding packaging mechanisms of $\mathrm{GH}$ molecules within a secretory granule came from the reports of Maji and co-workers showing that the hormone is stored as an amyloid (124, 125). Amyloids are defined by their highly organized cross B-sheet regions in protein aggregates and should be considered as yet another level of protein structure. The cross-B sheet represents a single structural epitope in which individual strands of each sheet run in perpendicular to the fibril axis while B-sheets are parallel to the fibril axis. These highly organized, elongated amyloid fibers are composed of thousands of copies of stacked B sheets composed of peptide/protein. These stacked fibers can trigger further refolding of the natively folded protein. In many proteins the amyloid state is thermodynamically stable at high concentration, but not energetically favorable at lower protein concentration (126). These fibrillary structures are often hallmarks of severe disorders; e.g., Alzheimer disease and diabetes mellitus.

Amino acid residues $72-82$ of the 191 amino acid, $22 \mathrm{kDa}$ rHGH monomer have a high aggregation propensity and 4 fibrillation segments, each of $\sim 6-10$ residues. These are $B$ aggregation "hot spots." Only $\mathrm{Zn}$ (II) ion, as the specific helper, allows fibrillation; yet even in this configuration, most of the molecule is able to maintain its globular fold (125)! The amyloid configuration not only may ensure efficient release of $22 \mathrm{kDa}$ $\mathrm{GH}$ from the amyloid depot, but also protect the $\mathrm{GH}$ from enzymatic degradation, high temperature, and large $\mathrm{pH}$ ranges. It is now well-accepted that many proteins can assume the amyloid configuration.

Mechanisms underlying amyloid fibril formation, and their relationships/ interactions (sometimes reversible) leading to the formation of either disordered, amorphous aggregates or oligomers (via on/off pathways), will lead to varied configurations of amyloid. These conformations are complex, dynamic and thought critical for understanding protein configuration in health and disease (126). Many proteins form amyloid-like fibrils in vitro. Obviously not all proteins are "bad." It must be recognized that common structural principles of amyloids convey their double nature as "good" or "bad" (127).

In the resting state, $\mathrm{GH}$ synthesis and processing of functional molecular aggregates (FA) ["good aggregated GH"] follow the regulated path to the cell surface and become primed for stimulated secretion into the blood. As the demand for $\mathrm{GH}$ increases with exercise stress, this process may result in errors in the biosynthetic pathway. Mechanisms to repair mis-folded, non-functional GH aggregates (NFA), are shown in Figure 2. As summarized by Frottin et al. (128) it has also become apparent that the nucleolus plays and important function in maintaining the homeostatic (proteostasis) quality control of aggregated proteins in the cell to prevent the formation of toxic aggregates or what might also be called non-functional aggregated proteins arising from aberrant cellular processing. Some NFA forms could be released into the circulation, however the concentration of circulating FA and NFA forms remains largely unknown. These

\section{PITUITARY SOMATOTRAPH}

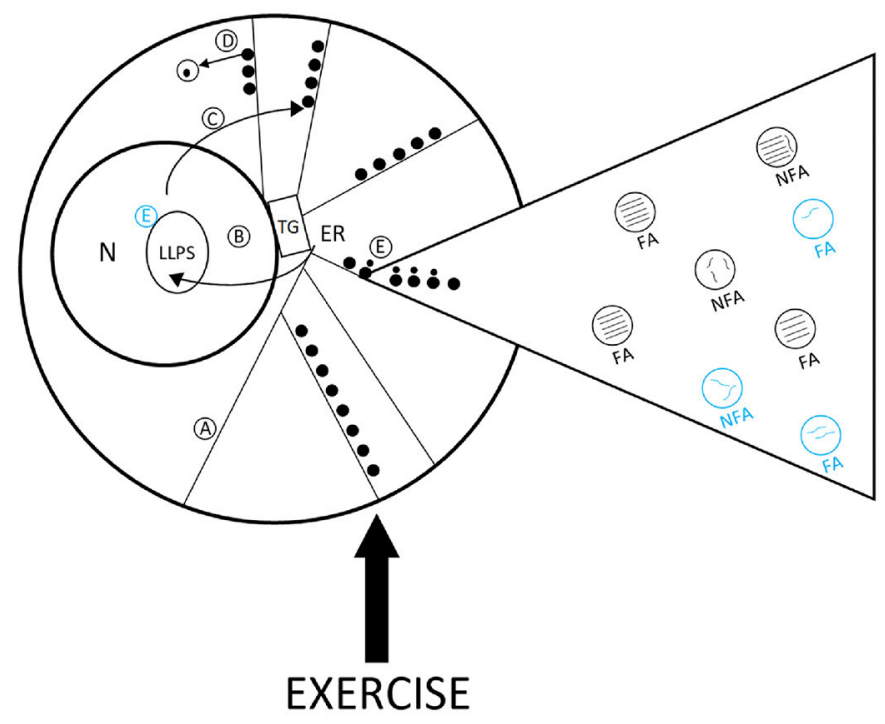

\author{
(A) $U P R R^{E R}$ \\ (B) UPR ${ }^{\mathrm{NUC}}$ \\ (C) REFOLDED PROTEIN \\ (D) AUTOPHAGY \\ (E) LLPS
}

Path $A$ : the unfolded protein response UPRer occurs in the trans Golgi (TG), endoplasmic reticulum (ER) area. Path B: Unfolded protein response continues in the nucleolus (UPRnu) with involvement of liquidliquid phase separation (LLPS [E]), chaperones and intermediate amyloid stage resulting in refolded protein (see Frottin et al. [128]). Path C: Refolded protein incorporated into early stage cytoplasmic $\mathrm{GH}$ granule formation. Path D: Destruction of defective GH granule via autophagy. Path E: LLPS mechanisms resulting in formation of a heterogeneous group of membrane-less organelles (e.g. stress granules) located in different nuclear and cytoplasmic sub-compartments. Stress granules are dynamic molecular complexes, existing in liquid droplets, which often contain different mRNA's and RNA binding proteins. They are thought to be equipped with varied stress response pathways. A single stress granule, located next to a $\mathrm{GH}$ secretion granule, is depicted at $\mathrm{E}$ and as such defines a proteostasis mechanism. Depending upon the physiological status of the pituitary host, granule cargo would be either functional aggregate or amyloid (FA) or non-functional aggregate or amyloid (NFA). See text.

FIGURE 2 | Theoretical model of proteostasis mechanisms likely to be active in the pituitary somatotroph during various types of human exercise stress. 
repair mechanisms may be enhanced with exercise training. This model suggests an intriguing line for future research in the quest to understand roles of aggregated GH in stress biology (129-131). The potential for lower values of BGH in the blood might be observed if all of the processing systems for mis-folded non-functional GH aggregates are fully engaged, potentially a training adaptation.

\section{Acute and Chronic Exercise Complexity Remains}

While the $\mathrm{GH}$ responses to exercise has been characterized for decades understanding the many selective roles in metabolism and other physiological mechanisms related to acute homeostasis and repair and remodeling of tissues remain needed $(94,132-$ 136). It becomes apparent that understanding the role(s) of $\mathrm{GH}$ in responding to exercise stress and adapting to exercise training is still in its embryonic stage. This becomes evident when one realizes that $\mathrm{GH}$ is not a single entity. The multitude of roles attributed to $\mathrm{GH}$ require that a more complex set of mediating mechanisms may be needed to accomplish them. As noted in this section the diversity of $\mathrm{GH}$ isoforms from their presence in the anterior pituitary to other biocompartments (e.g., brain, circulation, liver) also suggest that target cells may be responding to different GHs. The mere differences in receptor binding between bio and immune assays and their differential signaling raise questions as to their acute and chronic roles in exercise stress and adaptations. Additionally, growth hormone binding proteins from the liver and their potential to create dimers when binding to $22 \mathrm{kD}$ forms in the blood also raise questions as to how they function in signaling (137-139), yet while increases with acute resistance exercise are observed differences between trained and untrained men have not been observed (140).

Types of exercise may well have an influence as well (63). It may be due to total amount of work or the inability to activate the same motor unit array that contributes to such modality differences. One unifying thought is the influence of $\mathrm{pH}$ and $\mathrm{H}+$ ions on IGH (141). This is reflected in its close associations of blood lactate, that when lactate is elevated beyond the anaerobic threshold or is dramatically elevated with a resistance training workout, IGH is highly responsive (134, 142-145). This was demonstrated with resistance exercise in men and women in two studies by Kraemer's research groups $(144,145)$ where the short rest workouts using $1 \mathrm{~min}$ between sets and exercises demonstrated the highest blood lactate responses and IGH responses. Whether this is due to a reduction in the type 2 somatotrophs production less aggregate or a stimulation of predominantly type 1 somatotrophs is unknown. Other factors such as body fat of subjects to fasted or intakes of protein/carbohydrate before and/or after the workout also appear to influence IGH. Since the BGH studies have always been done in the fasted state, nothing is known as to its response patterns. Additionally, with the stability of the $\mathrm{BGH}$ in the blood how pulsatility of IGH interfaces with the entire signaling milieu remains to be elucidated.
Finally, how the various splice variants and aggregates of GH are integrated within the larger web of hormonal and molecular signaling remains to be seen as various studies continue to unravel the complex nature of homeostatic regulation with acute exercise and chronic exercise adaptations.

\section{CURRENT PERSPECTIVES ON IGF-I AND PHYSIOLOGICAL ADAPTATIONS AND COMPLEXITY RELATED TO THIS SUPERFAMILY TO TRAINING}

Insulin-like growth factors (IGFs) are small polypeptide hormones (70 and 67 amino acids for IGF-I and IGF-II, respectively), structurally related to insulin, and synthesized from a larger precursor peptide that is post-translationally processed into its active form. Of the two, IGF-I has been most extensively studied and is secreted as it is produced by the liver in response to GH stimulation. Only $2 \%$ of IGF-I circulates in its free form; most circulates as a binary (20-25\%) or ternary complex ( 75\%) (146-149). In its binary form, IGF-I circulates with one of seven binding proteins whereas in its ternary form, IGF-I circulates with IGFBP-3 and its acid labile subunit (ALS).

IGF-I $(7 \mathrm{kDa})$ is responsible for metabolic, mitogenic and anabolic cellular responses (150). It is produced locally (i.e., autocrine and paracrine mechanisms) in tissues and cells. IGFI acts as both a cell cycle initiation and progression factor. Its effects include satellite cell activation, proliferation, survival, and differentiation, increasing myotube size and number of nuclei per myotube, stimulating amino acid uptake and protein synthesis and muscle hypertrophy, neuronal myelinization, axonal sprouting and repairing damage, reducing chronic inflammatory response, increasing free fatty acid utilization, and enhancing insulin sensitivity upon receptor binding and subsequent intracellular signaling and glucose metabolism (1, 151). Expression and secretion of IGF-I increases by myofibers with mechanical loading (152). Secretion by myofibers stimulates autocrine and paracrine myofiber anabolic processes where adjacent satellite cells enter the cell cycle, proliferate, differentiate, fuse with myofibers, and provide myonuclei to maintain or reestablish the myonucleus to myofiber size ratios of the enlarged myofibers (152). Because of these critical anabolic functions, IGF genes have been considered a potential target for gene therapies, gene doping in athletes (153) and staving off advancing muscle weakness (154).

While liver-derived IGF-I is under direct regulation of $\mathrm{GH}$, local mechanical-stretch mechanisms can activate IGF-I synthesis in tissues. The potency of circulating IGF-I remains unclear and needs to be viewed in context with its binding proteins that provide fine tuning of the IGF actions and regulate bioavailability (150). Several studies have shown systemic elevations in IGF-I produced no elevations in protein synthesis or hypertrophy during resistance exercise training whereas upregulation in the muscle isoform was linked to significant muscle hypertrophy (151). 


\section{ACUTE RESPONSES AND CHRONIC ADAPTATIONS OF IGFS TO RESISTANCE TRAINING}

There remains much to discover about the roles of systemic vs. locally produced IGF-I in mediating the outcomes of resistance exercise (155). Yet, it appears that local IGF-I is consistently upregulated with both acute and chronic exercises; whereas in certain situations, circulating IGF-I may actually decrease, increase, or not change $(21,155)$. Studies showing no change in circulating IGF-I can vary due to the temporal frame of measurement following stimulation with GH (21). While the acute responses of IGF-I have been evaluated in the serum/plasma of many different studies of resistance exercise, its contribution to hypertrophy has been difficult to determine due to the milieu of anabolic signaling to skeletal muscle. Kraemer et al. were the first to demonstrate this highly variation to resistance exercise stress of IGF-I (119). However, there is little doubt, IGF-I is a primary player in anabolic signaling targeted to many tissues, including skeletal muscle. It could be that IGF-I acts as a signal that either amplifies or regulates skeletal muscle tissue repair and remodeling (1). Looking at the IGFBPs has provide a more fruitful area of study as they have shown a more reliable pattern of responses to acute resistance exercise protocols. Of importance is the response of IGFBPs which have generated more consistent responses with resistance exercise acutely elevating IGFBP-3 (21). Looking on longer term changes in IGF-I, Nindl et al. (148) monitored overnight IGF-I following heavy resistance exercise and showed IGF-I concentrations remained unaffected. However, IGFBP-2 increased and ALS decreased indicating that binding protein partitioning, rather than changes in systemic IGF-I, appeared to be an important finding. Exercise duration and total work also may impact IGFBP-1 changes but it was not see that the modality had as much impact on the response patterns. With the novel technique of microdialysis to measure IGF-I in the interstitial fluid, Nindl et al. (149) showed total and free IGF-I and IGFBP-3 were elevated. However, IGF-I in interstitial fluid was unaltered following high-power resistance type exercise. It was also observed that the IGF-I receptor phosphorylation was not increased but IGF mRNA content and Akt phosphorylation were increased (149) This supported the speculation that skeletal muscle adaptation is not be directly dependent on systemic IGF-I, but rather be involved with the interactions and signaling across different biocompartments.

Long term resistance exercise training studies examining resting circulating IGF-I concentrations have been demonstrated to be highly variable with reductions, no change, and elevations with no change or reductions in IGFBP-1 and IGFBP-3 (21). It has been demonstrated that in participants who are classified as extreme responders to a long term (16 wk) training program showed no significant changes in IGF-I, IGFBP-1, or IGFBP-3 but a trend showed that IGFBP-3 was lower in the non-responders (156). Resistance-trained men have been shown to have higher resting IGF-I values than untrained men (140) Nevertheless, single measurements of IGF-I need to be carefully interpreted as the roles and contributions remain speculative due to the multiple targets and mechanisms they are involved with in the signaling processes. Of more consequence may be the training responses of locally-produced IGF-I isoforms. Resistance exercise training of sufficient intensity and volume increases IGF-I and MGF mRNA for up to $48 \mathrm{~h}$ post RE $(21,157)$. Furthermore, IGFI and MGF mRNA have increased $2 \mathrm{~h}$ post exercise (but not $6 \mathrm{~h}$ ) after a single bout of moderate ( $65 \%$ of $1 \mathrm{RM} ; 18-20$ repetitions) and moderately-high ( $85 \%$ of $1 \mathrm{RM} ; 8-10$ repetitions) intensity resistance exercise training (158). Further studies have shown MGF acts independently and is expressed earlier than other IGF-I isoforms in response to resistance exercise training, and therefore may have greater anabolic potency (159). The recruitment of motor units and their associate muscle fibers creating mechanical damage appears to be an essential stimuli for local production of IGF-I.

\section{IGF-I RECEPTOR AND INTRACELLULAR SIGNALING}

Downstream actions of IGF-I are mediated through binding to the IGF-I receptor (IGF-IR), a ligand-activated receptor tyrosine kinase on the cell surface of target tissues. The IGF-IR gene is mapped to chromosome 15q25-26. Activation of receptor tyrosine kinase activity results from ligand binding to the $\alpha$ subunit of the receptor leading to a conformational change in the $\beta$ subunit (160). This leads to the activation of downstream signaling pathways of IGFs including PI 3-kinase pathway and Ras-mitogen-activated protein kinase (MAP kinase) pathway, for cell proliferation, cell differentiation and cell survival (160). Two types of IGF receptors have been identified. The type I receptor binds IGF-I with greater affinity than IGF-II and also interacts weakly with insulin. The type II receptor binds with greater affinity to IGF-II than IGF-I and does not bind to insulin (161). Resistance exercise influences IGF-IR phosphorylation where high-volume results in greater phosphorylation compared to high-intensity protocols $1 \mathrm{~h}$ post exercise (162). Resistance exercise protocols of moderate to high intensity also have been shown to increase IGF-IR mRNA $2 \mathrm{~h}$ following acute exercise (158). Mechanical stress also stimulates IGF-R signaling cascades via focal adhesion kinase (FAK), an attachment complex protein necessary for mechanical IGF-I-mediated hypertrophy in skeletal muscle cells (163). To the contrary, anabolic resistance and sarcopenia may be attributed to dysregulation in the IGF stimulated, Akt /Protein Kinase B and mechanistic target of rapamycin (mTOR) signaling pathways in response to resistance exercise and protein intake (164).

\section{INTEGRATED COMMUNICATION FOR ANABOLIC/CATABOLIC SIGNALING: GLUCOCORTICOIDS}

\section{Cortisol Regulation}

In addition to the anabolic hormones, glucocorticoids, mainly cortisol have a profound influence on human skeletal muscle (165). During stable physiological conditions, circulating cortisol exhibits a circadian rhythm peaking in the morning, slowly decreasing throughout the day, and reaching lowest levels around 
midnight (166) (Figure 3). Cortisol levels are regulated both at the systemic and tissue level to maintain glucocorticoid homeostasis. Endogenous levels of cortisol are systemically controlled by the hypothalamic-pituitary-adrenal (HPA) axis and locally by the action of $11 \beta$-hydroxysteroid dehydrogenase (11 $\beta$-HSD) enzymes. In the periphery, the cellular response to glucocorticoids differs by cell type (167-169), cell cycle stage (167), and exposure to stress (170).

In skeletal muscle, cortisol plays a fundamental role in regulating energy homeostasis and metabolism (171). During exercise, cortisol increases the availability of metabolic substrates, protects from immune cell activity, and maintains vascular integrity (172). The acute cortisol response to exercise is highest when the overall stress (volume and/or intensity of total work) of the training period is high $(145,173)$. Cortisol is also involved in adaptations to exercise by preparing the body for the next bout of exercise $(71,174)$, as increases in cortisol are prolonged before returning to basal levels following a bout of exercise. Adaptation of the HPA axis following exercise training is largely manifested by altered sensitivity to cortisol (172). Following acute exercise, there is an increased tissue sensitivity to glucocorticoids that serves to counteract muscle inflammation, cytokine synthesis, and muscle damage (172). Subsequent decreased sensitivity of monocytes to glucocorticoids $24 \mathrm{~h}$ following exercise may act to protect the body from prolonged, exercise-induced cortisol secretion (172). Inactivation of cortisol into cortisone acts as another mechanism to protect tissues and cells from the deleterious effects of exercise-related cortisol secretion (175). Inactivation of cortisol to cortisone appears to be an adaptation to exercise, given that athletes display a higher inactivation of cortisol into cortisone (175). However, overtraining appears to impair the inactivation of active cortisol to cortisone in athletes (175), and may impair anabolic processes as high levels of cortisol decrease skeletal IGF-I synthesis by reducing IGF-I transcript levels (176).

\section{TISSUE SPECIFIC REGULATION BY $11 \beta$-HSD (11 $\beta$-HYDROXYSTEROID DEHYDROGENASE)}

$11 \beta$-HSD (11 $\beta$-hydroxysteroid dehydrogenase) acts as a tissue specific regulator of glucocorticoid action by catalyzing the interconversion of active cortisol and corticosterone with inactive cortisone and 11-dehydrocorticosterone (177). This interconversion regulates glucocorticoid access to intracellular glucocorticoid receptors (178) and glucocorticoid action (179). The cellular hormonal environment can influence 11 $\beta$-HSD activity, where exposure to insulin, insulin-like growth factor I, and glucocorticoids can alter enzyme activity (179). Raised expression of $11 \beta$-HSD1 (Type 1) in skeletal muscle is believed to play role in mechanisms that contribute to the development of metabolic syndrome (180) insulin resistance (181), and hypertension (182).

\section{GLUCOCORTICOID RECEPTORS}

Glucocorticoids convey their signal mainly through intracellular glucocorticoid receptors, which in the absence of a ligand are generally localized to the cytosol (183). In the cytoplasm, the glucocorticoid receptor is found in a complex with chaperone proteins that maintain a conformation with high affinity binding

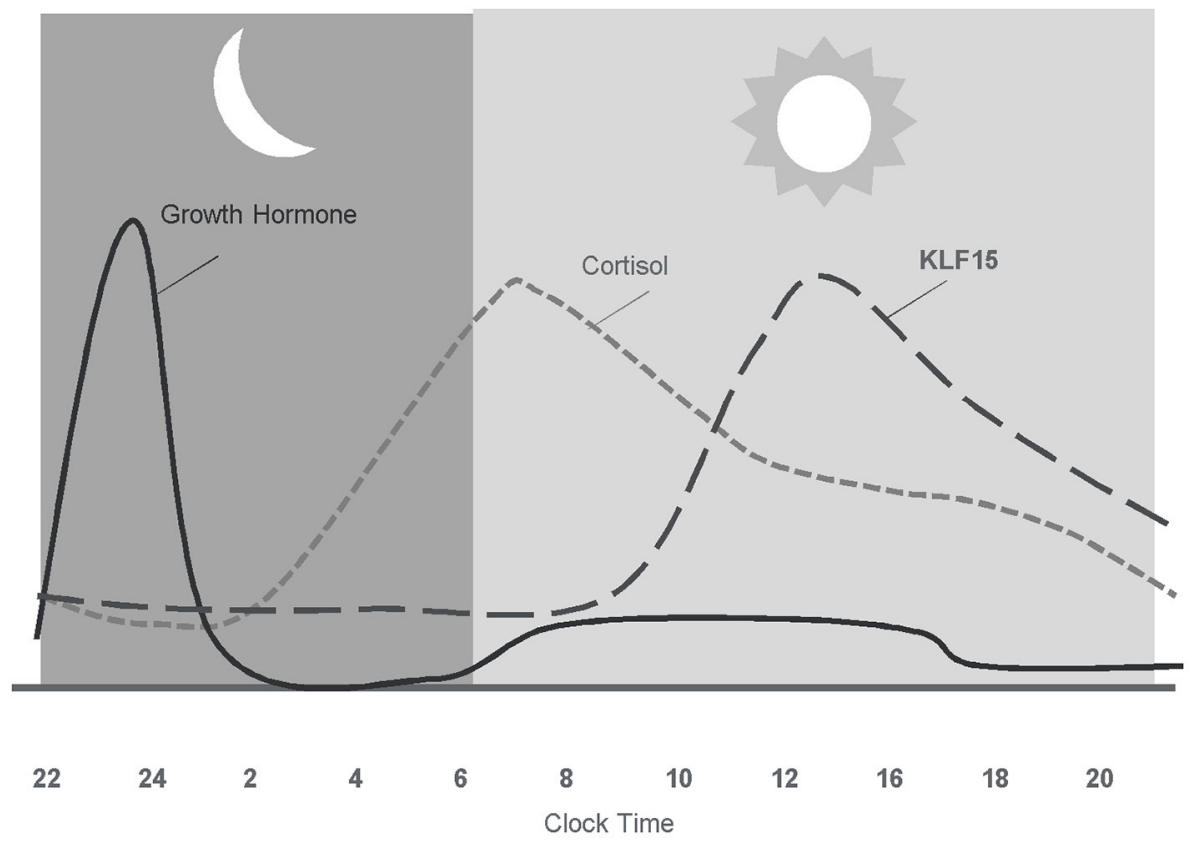

FIGURE 3 | Diurnal pattern of anabolic/catabolic regulators may facilitate anabolic benefit of intermittent exposure. 
potential (89). Once a glucocorticoid binds to the receptor, it moves to the nucleus where it interacts with specific DNA sequences known as glucocorticoid response elements $(183,184)$. Glucocorticoid response elements regulate the transcription of primary target genes by either directly binding to DNA (185), tethering onto other DNA-binding transcription factors (185), or through direct protein-protein interactions with other transcription factors and/or coregulators (186). Glucocorticoid receptor-binding to DNA is highly context specific and relies on the interplay of the receptor with other proteins $(187,188)$.

Selective targeting of glucocorticoid receptors is mediated by the combined action of cell-specific priming proteins, chromatin remodelers (189), and local sequence features (190). As much as $95 \%$ of glucocorticoid receptor binding sites are within preexisting sites of accessible chromatin (190), with some detected in remodeled chromatin $(189,190)$. Binding is dictated by proteins that maintain chromatin in an open state (188). Activator protein 1 (AP1) is one such protein that is involved in glucocorticoid receptor chromatin interactions and subsequent transcription and recruitment to co-occupied regulatory element (188). Most (62\%) GR-binding sites are occupied by the transcription factor $\mathrm{C} / \mathrm{EBP} \beta$ (enhancer-binding protein beta) (189), which regulate multiple genes in the ubiquitin-proteasome pathway (191).

During myogenesis, glucocorticoid receptors are localized in different parts of cells: in the cytoplasm of myoblasts, in the nucleus of myotubes, and in the extracellular matrix, satellite cells, and near mitochondria in mature skeletal muscle fibers in mice (192). Yet, location may differ by fiber type, as most muscle fiber types express glucocorticoid receptors in the cytosol, but only slow fibers express glucocorticoid receptors on the membrane (193). Membrane glucocorticoid receptors are localized in the extracellular matrix and signal rapidly (within $5 \mathrm{~min}$ ) through the MAPK pathway in mammalian skeletal muscle fibers (192).

\section{Glucocorticoid Receptor Isoforms}

The human glucocorticoid receptor is encoded by the NR3C1 gene, located on chromosome 5 (5q31-32) (194), and consists of nine exons (195). There are two major isoforms of glucocorticoid receptor due to alternative splicing of a single gene: GR $\alpha$ and GR $\beta$ (196). These isoforms differ at their carboxyl termini (195) (Figure 4). GR $\beta$ has a truncated glucocorticoid ligand-binding domain, which prevents glucocorticoid binding and causes GR $\beta$ to act as a dominant negative inhibitor of $\operatorname{GR} \alpha(195,196)$.
In healthy humans, the default splicing pathway is the one leading to GR $\alpha$ (197), with minimal activation of the alternative splicing event leading to GR $\beta$ (197). While there are two main isoforms of the glucocorticoid receptor, more than 1,500 variants have been identified and cataloged (198). Such variants include both naturally occurring and stress-induced GR isoforms, where further studies are needed to decipher their roles in stress responses (198). In healthy human cells and tissues, GR $\alpha$ mRNA concentrations are highest in the brain, followed by skeletal muscle, macrophages, lungs, kidneys, liver, heart, eosinophils, peripheral blood mononuclear cells, nasal mucosa, neutrophils, and colon (197). GR $\beta$ mRNA expression which is lower than $\mathrm{GR} \alpha$ mRNA expression, with the highest concentrations found in eosinophils, followed by peripheral blood mononuclear cells, liver, skeletal muscle, kidney, macrophages, lung, neutrophils, brain, nasal mucosa, and heart (197).

The relative expression of the two alternatively spliced glucocorticoid isoforms and the ratio of GR- $\alpha$ to GR- $\beta$ expression modulates cellular sensitivity to glucocorticoids (199). Expression of GR $\beta$ selectively increases in cells exposed to inflammatory signals; this increased expression leads to glucocorticoid resistance $(196,200)$ and may reduce the therapeutic potential of glucocorticoids (201). In myoblasts, glucocorticoid exposure results in a dose-dependent decline in GR $\alpha$ expression and a dose-dependent increase in GR $\beta$ expression (179). In myotubes, overexpression of GR $\beta$ is associated with a blunted catabolic response to glucocorticoids via lower "atrogene" signals (201). Mechanistically, the selective increase in GR $\beta$ appears to involve the splicing factor SRp30c (serine/arginine-rich protein p30c) $(202,203)$. On the other hand, agents that increase GR $\alpha$ expression sensitize cells to glucocorticoids (204). Exercise affects receptor expression (205) and relative expression of receptor isoforms; athletes show less $\mathrm{GR} \alpha \mathrm{mRNA}$ expression in peripheral blood mononuclear cells than do untrained controls, indicating reduced sensitivity (206). Yet, GR- $\beta$ does not appear involved in exercise adaptations in peripheral blood mononuclear cells of athletes (206).

\section{GR $\alpha$ Isoform Signal}

In skeletal muscle, glucocorticoid hormone action is determined principally by binding to the GR $\alpha$ isoform (179) which can increase or decrease glucocorticoid receptor gene products that contribute to physiologic responses (207) (Figure 5). The binding of glucocorticoids to the ligand-binding domain of GR $\alpha$ causes translocation to the nucleus and binding to glucocorticoid

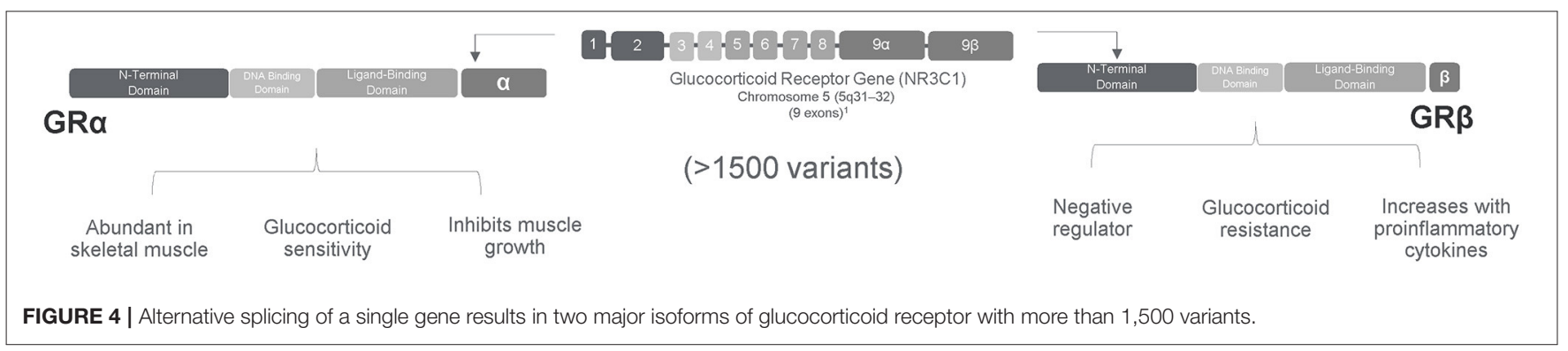




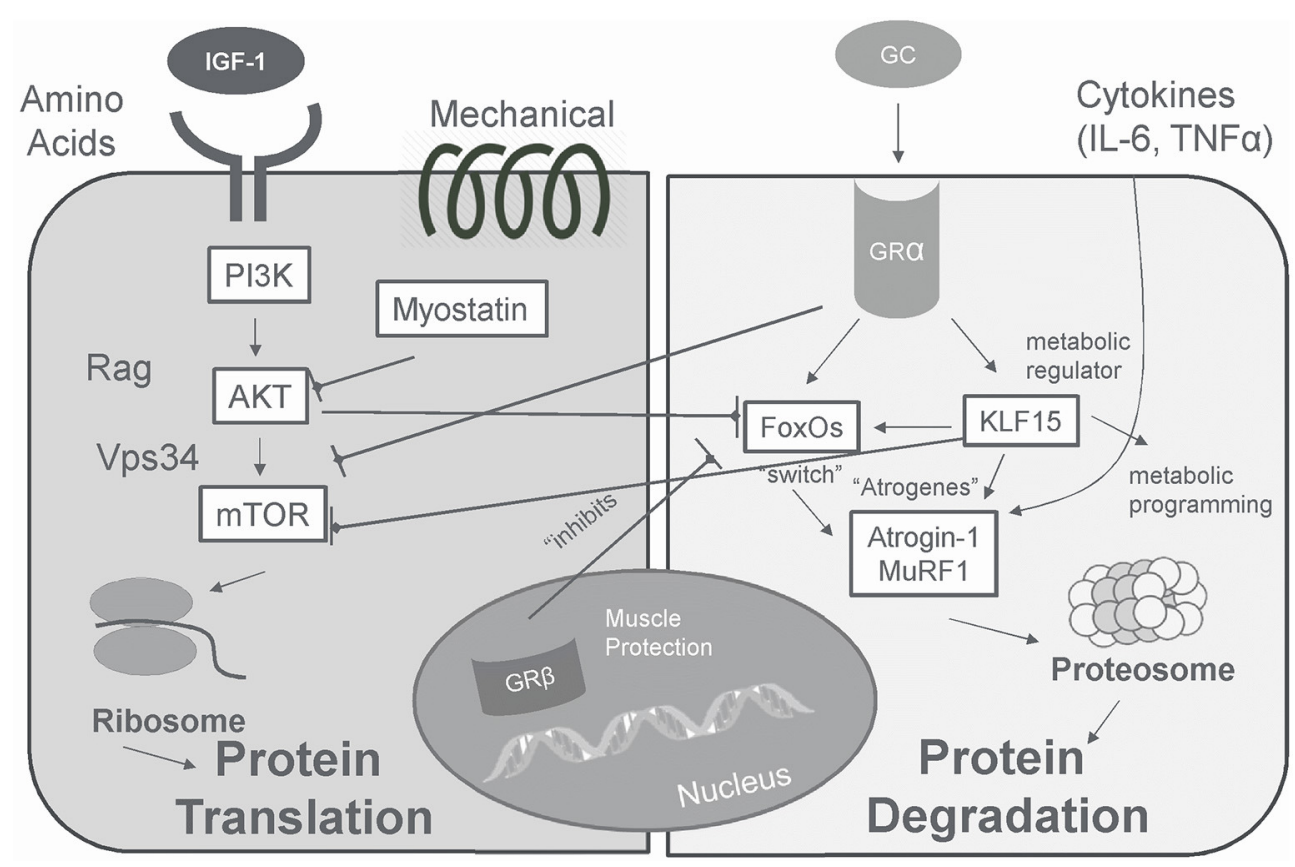

FIGURE 5 | In skeletal muscle glucocorticoids produce a catabolic effect that is opposite that of insulin/IGF-I via GR $\alpha$.

response elements (GREs) in the promoter region of genes (201). Specifically, GR $\alpha$ binds to GREs in the promoter of forkhead box O (FOXO) transcription factors and enhances expression (208). This results in a FOXO-dependent increase in muscle atrophy F-box/Atrogen-1 (MAFbx) and muscle ring finger 1 (MuRF1), E3 ubiquitin ligases necessary for glucocorticoid -induced muscle myopathy; suppression of MAFbx and MuRF1 inhibits glucocorticoid -induced protein degradation (208). In addition, glucocorticoids may also exert actions through tethering (GR binding to other transcription regulators) and squelching (GR binding to and taking away transcription regulator from DNA), which often lead to transcription repression (185).

\section{Proteolysis Signal}

The catabolic actions of cortisol resulting in muscle proteolysis occur largely via the ubiquitin-proteasome and lysosomal systems $(186,209-211)$. Via these proteolytic systems, expression of genes involved in atrophy ("atrogenes") are increased, which target proteins for degradation by the proteasome machinery (210). Atrogenes include transcription factor FOXO, a major switch for the stimulation of several atrogenes, and two ubiquitin ligases atrogin-1 and MuRF-1, involved in the targeting of protein to be degraded by the proteasome machinery, and LC3 $(186,201$, 209, 210). Glucocorticoids also may blunt skeletal muscle protein synthesis by inhibiting IGF-I signaling, a muscle anabolic growth factor, and increasing myostatin signaling, a muscle catabolic growth factor, contributing to muscle atrophy $(207,209,210)$.

\section{GR Receptor Expression in Skeletal Muscle}

In skeletal muscle, glucocorticoid receptor expression is more abundant in fast than slow twitch fibers $(211,212)$. Consequently, slow twitch muscle fibers appear to be resistant to the catabolic action of glucocorticoids (213) whereas, fast twitch muscle fibers are more sensitive to the catabolic action of glucocorticoids (214). Glucocorticoid-induced muscle catabolism results from degradation of contractile proteins which begins in the myosin filaments and then spreads to the thin filaments and the $\mathrm{z}$ line (213). In fast fibers, glucocorticoid exposure in the absence of exercise increases the activity of non-lysosomal proteases (214). Yet, in response to exercise, both fast and slow fibers experience increases in myofibrillar protease activity followed by anti-catabolic actions (214). While GR expression does not appear to change following resistance exercise (76), receptor activation occurs at a rate that is independent of both fiber type and delivery of steroid to working muscles during exercise (215).

\section{GR $\beta$ Isoform Signal (Negative Regulator)}

$\mathrm{GR} \beta$ functions as a negative regulator of glucocorticoid actions in local tissues (168), where overexpression of GR $\beta$ is associated with glucocorticoid resistance. Like other nuclear receptors, the GR $\beta$ functions as a naturally occurring dominant negative isoform that blocks the activity of GR $\alpha$ when the two are coexpressed in the same cell $(195,216)$. The negative action is largely caused by the formation of inactive, or weakly active, heterodimers between $\operatorname{GR} \alpha$ and $\operatorname{GR} \beta(216,217)$. Unlike the $\mathrm{GR} \alpha, \mathrm{GR} \beta$ has a truncated ligand-binding domain that prevents glucocorticoid binding and causes glucocorticoid resistance (195, 201). The dominant negative activity of GR $\beta$ resides within its unique carboxyl-terminal 15 amino acids (217). In addition, unlike GR $\alpha, \operatorname{GR} \beta$ is located primarily in the nucleus of cells independent of hormone administration (195). In the absence 
of $\mathrm{GR} \alpha, \mathrm{GR} \beta$ is transcriptionally inactive on a glucocorticoidresponsive enhancer (195). When both GR $\alpha$ and GR $\beta$ isoforms are expressed in the same cell, GR $\beta$ inhibits the hormone-induced $\mathrm{GR} \alpha$-mediated stimulation of gene expression (195). Compared to $\mathrm{GR} \alpha, \mathrm{GR} \beta$ does not undergo ligand-induced down regulation and has an increased half-life (195). Elevated levels of GR $\beta$ in immune cells correlate with reduced sensitivity to glucocorticoids (168). Expression of GR $\beta$ in cells is increased by proinflammatory cytokines [interleukins IL-1, $-2,-4,-7,-8$ and -18; tumor necrosis factor -alpha (TNF $\alpha)$; and interferons $\alpha$ and $\gamma](168,200)$.

$\mathrm{GR} \beta$ is responsible for the development of tissue-specific resistance to glucocorticoids in various disorders associated with dysregulation of immune function (168). Increased GR $\beta$ expression has been linked to glucocorticoid resistance in asthma, leukemia, cancer, and inflammation (201). GR $\beta$ expression in human neutrophils may also provide a mechanism by which cells escape glucocorticoid-induced cell death (218). Cell survival is further enhanced by upregulation of GR $\beta$ by proinflammatory cytokines such as IL- 8 in the presence of glucocorticoids during inflammation (218). Anti-GR $\beta$ molecules have become a target of cancer therapies as GR $\beta$ has been shown to be highly expressed in cells from solid and liquid tumor, and blocking them may repress cell migration (219). On the other hand, GR $\beta$ may serve as a pharmacological target for skeletal muscle growth and protection from glucocorticoid-induced catabolic signaling (201). Increased expression of GR $\beta$ promotes glucocorticoid resistance in skeletal muscle, thus stabilizing muscle mass during exposure to high doses of glucocorticoids (201).

Muscle protection via GR $\beta$ is associated with increased levels of muscle regulatory factors, enhanced proliferation in myoblasts, and increased myotube fusion (201). Myotubes overexpressing GR $\beta$ have lower forkhead box O3 (FOXO3a) mRNA levels and a blunted muscle atrophy F-box/atrogen1 (MAFbx) and muscle ring finger 1 (MuRF1) response to glucocorticoids (201). GR $\beta$ also enhances insulin-stimulated growth through suppressed phosphatase and tensin homolog (PTEN) gene expression and increased phosphorylation of Akt (220). Moreover, overexpression of GR $\beta$ may preserve skeletal muscle mass in the presence of glucocorticoids by increased MyoD (1.8-fold) and myogenin (2.5-fold) gene expression, two muscle regulatory factors necessary for skeletal muscle development and regeneration (201). In addition, overexpression of GR $\beta$ enhances myotube formation and reduces glucocorticoid responsiveness in mouse muscle cells (201). Another protective mechanism by which GR $\beta$ contributes to preserved muscle mass may be through repression of the tumor necrosis (TNF) $\alpha$ and interleukin (IL)-6 genes (221), and inhibited GR $\alpha$ mediated repression of an NF-kappaB-responsive promoter (217). Yet, glucocorticoid exposure alone does not appear to impact GR $\beta$ protein levels in mouse muscle cells (201) and human cells (222).

To the contrary, insulin exposure increases GR $\beta$ protein expression (201). Thus, insulin resistance in response to glucocorticoid therapy may contribute to muscle atrophy via reduced protein synthesis and increased protein degradation by genomic and non-genomic interference with several kinases in the insulin-signaling pathway
(201). Although further work is needed to determine the impact of physical exercise training on GR $\beta$, studies in human myoblast and myotube cultures (without neural innervation, mechanical loading, and in vivo conditions) revealed that treatment with glucocorticoids alone may not be sufficient to elicit changes in GR $\alpha$ or GR $\beta$ mRNA or protein expression (222).

\section{Glucocorticoid Sensitivity}

Sensitivity to glucocorticoids varies among individuals, among tissues from the same individual, and even within the same cell depending on the phase of the cell cycle (223). Hereditary studies show that differences in the glucocorticoid receptor gene make $6.6 \%$ of the normal population relatively hypersensitive to glucocorticoids, and $2.3 \%$ relatively resistant (169). Yet, glucocorticoid resistance may also be acquired and localized to the sites of inflammation (169) with pathological conditions (224). Glucocorticoid sensitivity is largely determined by a number of factors including the intracellular density and distribution of glucocorticoid receptors (183), 11ßHSD1-mediated intracellular synthesis of active cortisol from inactive cortisone (179), tissue-specific presence of coregulatory proteins, the phosphorylation status of GR, the sequence of the GR-binding site and flanking DNA on target genes $(184,225)$, post-translational modifications of GR, the availability of specific co-activators and co-repressors, epigenetic regulators, the chromatin landscape $(187,190)$, and cross-talk with MyoD family inhibitor domain-containing proteins (226).

With exercise training, the body adapts to regulate glucocorticoid sensitivity in some cell types (172). Increased tissue sensitivity to glucocorticoids following (6-24h) acute exercise may serve to counteract muscle inflammatory reaction and cytokine synthesis and then decrease exerciseinduced muscle damage or inflammatory response (172). Subsequent decreased sensitivity of monocytes to glucocorticoids $24 \mathrm{~h}$ following exercise may act to protect the body from prolonged, exercise-induced cortisol secretion (172). Intracellular adaptation of glucocorticoid regulators to exercise is tissue specific, resulting in decreases in glucocorticoid action in skeletal muscle and increases in glucocorticoid action in the liver and visceral fat (227). While exercise attenuates glucocorticoid induced muscle atrophy (228), glucocorticoid exposure (via prednisolone exposure) reduces exercise performance, increases blood glucose concentrations and white blood cell counts and alters Leydig cell function (229).

\section{KLF15-A TARGET OF GLUCOCORTICOID RECEPTOR IN SKELETAL MUSCLE}

A peripheral clock system is present in a human adrenocortical cells where periodic oscillations of clock genes are influenced by glucocorticoids, mainly through GR $\alpha$ (230). In human leukocytes, glucocorticoid receptor expression parallels that of plasma cortisol with values peaking in the morning at 
04:00-08:00 $\mathrm{h}$ and being lowest at 23:00-24:00 $\mathrm{h}$ (231). The diurnal variations in the glucocorticoid receptor may serve to coordinate the reactivity of the target cells to cortisol (231). Corresponding to the peripheral clock system are responses to glucocorticoid exposure where, although chronic and sustained exposure to glucocorticoids promotes catabolic consequences for skeletal muscle, intermittent exposure appears to have a more favorable impact $(232,233)$. In fact, intermittent administration of glucocorticoids appears to promote sarcolemmal repair and muscle recovery from injury (232) and muscle performance (233). In contrast, sustained glucocorticoid exposure induces muscle atrophy. Differences in muscle responses to intermittent compared to sustained exposure to glucocorticoids are likely mediated by transcription factor KLF15, which also increases with weekly exposure, but is suppressed with daily exposure (232).

Transcription factor Kruppel-like factor 15 (KLF15) is a direct target of the glucocorticoid receptor in skeletal muscle (212). Within skeletal muscle it regulates lipid utilization (234), coordinates the transcriptional circuitry responsible for metabolism (234), mediates the metabolic ergogenic effects of glucocorticoids via metabolic programming (233), and affects exercise capacity $(212,234)$. In addition to its metabolic role, KLF15 regulates myofiber typing (235), mTOR activity (233), and myofiber size (212). KLF15 displays a diurnal pattern of expression, and regulates branchedchain amino acid (BCAA) metabolism and utilization in a circadian fashion (236). Glucocorticoid exposure (237), acute endurance exercise (234), and hyperglycemia lead to increased KLF15 expression. As a direct target gene of the glucocorticoid receptor with a diurnal response pattern, KLF15 signaling may explain the complex role of glucocorticoids in metabolism and protein balance and mechanistically favor the intermittent value of glucocorticoids via exercise or pharmaceuticals.

\section{REFERENCES}

1. Kraemer WJ, Ratamess NA, Nindl BC. Recovery responses of testosterone, growth hormone, and IGF-1 after resistance exercise. J Appl Physiol. (2017) 122:549-58. doi: 10.1152/japplphysiol.00599.2016

2. Vingren JL, Kraemer WJ, Ratamess NA, Anderson JM, Volek JS, Maresh CM. Testosterone physiology in resistance exercise and training: the up-stream regulatory elements. Sports Med. (2010) 40:1037-53. doi: 10.2165/11536910-000000000-00000

3. Pollanen E, Kangas R, Horttanainen M, Niskala P, Kaprio J, Butler-Browne G, et al. Intramuscular sex steroid hormones are associated with skeletal muscle strength and power in women with different hormonal status. Aging Cell. (2015) 14:236-48. doi: 10.1111/acel.12309

4. Bhasin S, Travison TG, Storer TW, Lakshman K, Kaushik M, Mazer NA, et al. Effect of testosterone supplementation with and without a dual $5 \alpha$-reductase inhibitor on fat-free mass in men with suppressed testosterone production: a randomized controlled trial. JAMA. (2012) 307:931-9. doi: 10.1001/jama.2012.227

5. Borst SE, Yarrow JF, Conover CF, Nseyo U, Meuleman JR, Lipinska JA, et al. Musculoskeletal and prostate effects of combined testosterone and finasteride administration in older hypogonadal men:a randomized,

\section{CONCLUSIONS}

Hormones are largely responsible for the integrated communication network responsible for modulating cellular signaling for protein synthesis (165). All aspects from production, release, transportation, and tissue uptake to intracellular signaling affect the cell signaling and communication that govern basic activities of cells and coordinate all cellular actions. Among the "anabolic giants," testosterone is the primary anabolic hormone in men. It's anabolic influence largely dictated through genomic and nongenomic signaling, satellite cell activation, interaction with other anabolic signaling pathways, upregulation or downregulation of the androgen receptor, and potential roles in co-activators and transcriptional activity. Growth hormones exhibit differential influences depending on the "type" of the hormone being assayed and the magnitude of the physiological stress. The actions of IGF-I are regulated by a family of binding proteins (IGFBPs 1-6), which can either stimulate or inhibit biological action depending on binding. Circadian patterning and newly discovered variants of glucocorticoid isoforms largely dictate glucocorticoid sensitivity and catabolic, muscle sparing, or pathological influence. The downstream integrated anabolic and catabolic mechanisms of these hormones not only affect the ability of skeletal muscle to generate force, they also have implications in pharmaceutical treatments (238), aging (176), metabolic syndrome (180), insulin resistance (181), and hypertension (182). Thus, advances in our understanding of hormones that impact anabolic: catabolic processes have relevance for athletes and the general population, alike.

\section{AUTHOR CONTRIBUTIONS}

$\mathrm{WK}, \mathrm{NR}, \mathrm{WH}, \mathrm{BN}$, and MF contributed to the conception of the work, drafting the article, critical revision of the article, and final approval of the version to be published.

controlled trial. Am J Physiol Endocrinol Metab. (2014) 306:E43342. doi: 10.1152/ajpendo.00592.2013

6. MacLean HE, Chiu WS, Notini AJ, Axell AM, Davey RA, McManus JF, et al. Impaired skeletal muscle development and function in male, but not female, genomic androgen receptor knockout mice. FASEB J. (2008) 22:2676-89. doi: 10.1096/fj.08-1 05726

7. Rossetti ML, Steiner JL, Gordon BS. Androgen-mediated regulation of skeletal muscle protein balance. Mol Cell Endocrinol. (2017) 447:35-44. doi: 10.1016/j.mce.2017. 02.031

8. Mobley CB, Mumford PW, Kephart WC, Conover CF, Beggs LA, Balaez A, et al. Effects of testosterone treatment on markers of skeletal muscle ribosome biogenesis. Andrologia. (2016) 48:967-77. doi: 10.1111/and.12539

9. Jardi F, Laurent MR, Dubois V, Kim N, Khalil R, Decallonne B, et al. Androgen and estrogen actions on male physical activity: a story beyond muscle. J Endocrinol. (2018) 238:R31-52. doi: 10.1530/JOE18-0125

10. McIlwraith EK, Belsham DD. Phoenixin: uncovering its receptor, signaling and functions. Acta Pharmacol Sin. (2018) 39:774-8. doi: 10.1038/aps.2018.13 
11. Ratnasabapathy R, Dhillo WS. The effects of kisspeptin in human reproductive function - therapeutic implications. Curr Drug Targets. (2013) 14:365-71. doi: 10.2174/138945013804998981

12. Dudek M, Ziarniak K, Sliwowska JH. Kisspeptin and metabolism: the brain and beyond. Front Endocrinol. (2018) 9:145. doi: 10.3389/fendo.2018.00145

13. Khajehnasiri N, Khazali H, Sheikhzadeh F. Various responses of male pituitary-gonadal axis to different intensities of long-term exercise: Role of expression of KNDYrelated genes. J Biosci. (2018) 43:56974. doi: 10.1007/s12038-018-9782-1

14. Matsui $H$, Asami T. Effects and therapeutic potentials of kisspeptin analogs: regulation of the hypothalamic-pituitary-gonadal axis. Neuroendocrinology. (2014) 99:49-60. doi: 10.1159/000357809

15. Enea C, Boisseau N, Fargeas-Gluck MA, Diaz V, Dugue B. Circulating androgens in women: exercise-induced changes. Sports Med. (2011) 41:115. doi: 10.2165/11536920-000000000-00000

16. Sato K, Iemitsu M. Exercise and sex steroid hormones in skeletal muscle. J Steroid Biochem Mol Biol. (2015) 145:2005. doi: 10.1016/j.jsbmb.2014.03.009

17. Vingren JL, Kraemer WJ, Hatfield DL, Anderson JM, Volek JS, Ratamess NA, et al. Effect of resistance exercise on muscle steroidogenesis. J Appl Physiol. (2008) 105:1754-60. doi: 10.1152/japplphysiol.91235.2008

18. Hammes A, Andreassen TK, Spoelgen R, Raila J, Hubner N, Schulz H, et al. Role of endocytosis in cellular uptake of sex steroids. Cell. (2005) 122:751-62. doi: 10.1016/j.cell.2005.06.032

19. Poole CN, Roberts MD, Dalbo VJ, Sunderland KL, Kerksick CM. Megalin and androgen receptor gene expression in young and old human skeletal muscle before and after three sequential exercise bouts. J Strength Cond Res. (2011) 25:309-17. doi: 10.1519/JSC.0b013e318202e45d

20. Michels G, Hoppe UC. Rapid actions of androgens. Front Neuroendocrinol. (2008) 29:182-98. doi: 10.1016/j.yfrne.2007.08.004

21. Kraemer WJ, Ratamess NA. Hormonal responses and adaptations to resistance exercise and training. Sports Med. (2005) 35:33961. doi: 10.2165/00007256-200535040-00004

22. Ahtiainen JP, Pakarinen A, Alen M, Kraemer WJ, Hakkinen K. Muscle hypertrophy, hormonal adaptations and strength development during strength training in strength-trained and untrained men. Eur J Appl Physiol. (2003) 89:555-63. doi: 10.1007/s00421-003-0833-3

23. Ahtiainen JP, Pakarinen A, Alen M, Kraemer WJ, Hakkinen K. Short vs. long rest period between the sets in hypertrophic resistance training: influence on muscle strength, size, and hormonal adaptations in trained men. J Strength Cond Res. (2005) 19:572-82. doi: 10.1519/00124278-200508000-00015

24. Hansen S, Kvorning T, Kjaer M, Sjogaard G. The effect of shortterm strength training on human skeletal muscle: the importance of physiologically elevated hormone levels. Scand J Med Sci Sports. (2001) 11:347-54. doi: 10.1034/j.1600-0838.2001.110606.x

25. Spiering BA, Kraemer WJ, Vingren JL, Ratamess NA, Anderson $\mathrm{JM}$, Armstrong LE, et al. Elevated endogenous testosterone concentrations potentiate muscle androgen receptor responses to resistance exercise. J Steroid Biochem Mol Biol. (2009) 114:195-9. doi: 10.1016/j.jsbmb.2009.02.005

26. West DW, Phillips SM. Associations of exercise-induced hormone profiles and gains in strength and hypertrophy in a large cohort after weight training. Eur J Appl Physiol. (2012) 112:2693-702. doi: 10.1007/s00421-011-2246-Z

27. Kvorning T, Andersen M, Brixen K, Schjerling P, Suetta C, Madsen K. Suppression of testosterone does not blunt mRNA expression of myoD, myogenin, IGF, myostatin or androgen receptor post strength training in humans. J Physiol. (2007) 578:579-93. doi: 10.1113/jphysiol.2006.122671

28. Sculthorpe N, Solomon AM, Sinanan AC, Bouloux PM, Grace F, Lewis MP. Androgens affect myogenesis in vitro and increase local IGF-1 expression. Med Sci Sports Exerc. (2012) 44:610-5. doi: 10.1249/MSS.0b013e318237c5c0

29. Ye F, McCoy SC, Ross HH, Bernardo JA, Beharry AW, Senf SM, et al. Transcriptional regulation of myotrophic actions by testosterone and trenbolone on androgen-responsive muscle. Steroids. (2014) 87:5966. doi: 10.1016/j.steroids.2014.05.024

30. Sato K, Iemitsu M, Matsutani K, Kurihara T, Hamaoka T, Fujita S. Resistance training restores muscle sex steroid hormone steroidogenesis in older men. FASEB J. (2014) 28:1891-7. doi: 10.1096/fj.13-245480
31. Morton RW, Sato K, Gallaugher MPB, Oikawa SY, McNicholas PD, Fujita S, et al. Muscle androgen receptor content but not systemic hormones is associated with resistance training-induced skeletal muscle hypertrophy in healthy, young men. Front Physiol. (2018) 9:1373. doi: 10.3389/fphys.2018.01373

32. Brooks BP, Merry DE, Paulson HL, Lieberman AP, Kolson DL, Fischbeck KH. A cell culture model for androgen effects in motor neurons. J Neurochem. (1998) 70:1054-60. doi: 10.1046/j.1471-4159.1998.70031054.x

33. Davey RA, Clarke MV, Russell PK, Rana K, Seto J, Roeszler KN, et al. Androgen Action via the androgen receptor in neurons within the brain positively regulates muscle mass in male mice. Endocrinology. (2017) 158:3684-95. doi: 10.1210/en.2017-00470

34. Dent JR, Fletcher DK, McGuigan MR. Evidence for a non-genomic action of testosterone in skeletal muscle which may improve athletic performance: implications for the female athlete. J Sports Sci Med. (2012) 11:363-70.

35. Hamdi MM, Mutungi G. Dihydrotestosterone activates the MAPK pathway and modulates maximum isometric force through the EGF receptor in isolated intact mouse skeletal muscle fibres. J Physiol. (2010) 588:51125. doi: 10.1113/jphysiol.2009.182162

36. Basualto-Alarcon C, Jorquera G, Altamirano F, Jaimovich E, Estrada M. Testosterone signals through mTOR and androgen receptor to induce muscle hypertrophy. Med Sci Sports Exerc. (2013) 45:171220. doi: 10.1249/MSS.0b013e31828cf5f3

37. White JP, Gao S, Puppa MJ, Sato S, Welle SL, Carson JA. Testosterone regulation of Akt/mTORC1/FoxO3a signaling in skeletal muscle. Mol Cell Endocrinol. (2013) 365:174-86. doi: 10.1016/j.mce.2012.10.019

38. Zeng F, Zhao H, Liao J. Androgen interacts with exercise through the mTOR pathway to induce skeletal muscle hypertrophy. Biol Sport. (2017) 34:313-21. doi: 10.5114/biolsport.2017.69818

39. MacKrell JG, Yaden BC, Bullock H, Chen K, Shetler P, Bryant HU, et al. Molecular targets of androgen signaling that characterize skeletal muscle recovery and regeneration. Nucl Recept Signal. (2015) 13:e005. doi: 10.1621/nrs.13005

40. Braga M, Bhasin S, Jasuja R, Pervin S, Singh R. Testosterone inhibits transforming growth factor-beta signaling during myogenic differentiation and proliferation of mouse satellite cells: potential role of follistatin in mediating testosterone action. Mol Cell Endocrinol. (2012) 350:3952. doi: 10.1016/j.mce.2011.11.019

41. Kovacheva EL, Hikim AP, Shen R, Sinha I, Sinha-Hikim I. Testosterone supplementation reverses sarcopenia in aging through regulation of myostatin, c-Jun NH2-terminal kinase, Notch, and Akt signaling pathways. Endocrinology. (2010) 151:628-38. doi: 10.1210/en.2009-1177

42. Singh R, Artaza JN, Taylor WE, Gonzalez-Cadavid NF, Bhasin S. Androgens stimulate myogenic differentiation and inhibit adipogenesis in $\mathrm{C} 3 \mathrm{H}$ $10 \mathrm{~T} 1 / 2$ pluripotent cells through an androgen receptor-mediated pathway. Endocrinology. (2003) 144:5081-8. doi: 10.1210/en.2003-0741

43. Dubois V, Laurent MR, Sinnesael M, Cielen N, Helsen C, Clinckemalie $\mathrm{L}$, et al. A satellite cell-specific knockout of the androgen receptor reveals myostatin as a direct androgen target in skeletal muscle. FASEB J. (2014) 28:2979-94. doi: 10.1096/fj.14-249748

44. Mumford PW, Romero MA, Mao X, Mobley CB, Kephart WC, Haun CT, et al. Cross talk between androgen and Wnt signaling potentially contributes to age-related skeletal muscle atrophy in rats. J Appl Physiol. (2018) 125:48694. doi: 10.1152/japplphysiol.00768.2017

45. Spillane M, Schwarz N, Willoughby DS. Upper-body resistance exercise augments vastus lateralis androgen receptor-DNA binding and canonical $\mathrm{Wnt} / \beta$-catenin signaling compared to lower-body resistance exercise in resistance-trained men without an acute increase in serum testosterone. Steroids. (2015) 98:63-71. doi: 10.1016/j.steroids.2015.02.019

46. Ophoff J, Van Proeyen K, Callewaert F, De Gendt K, De Bock K, Vanden Bosch A, et al. Androgen signaling in myocytes contributes to the maintenance of muscle mass and fiber type regulation but not to muscle strength or fatigue. Endocrinology. (2009) 150:355866. doi: 10.1210/en.2008-1509

47. Inoue K, Yamasaki S, Fushiki T, Okada Y, Sugimoto E. Androgen receptor antagonist suppresses exercise-induced hypertrophy of skeletal muscle. Eur J Appl Physiol Occup Physiol. (1994) 69:88-91. doi: 10.1007/BF00867933 
48. Deschenes MR, Maresh CM, Armstrong LE, Covault J, Kraemer WJ, Crivello JF. Endurance and resistance exercise induce muscle fiber type specific responses in androgen binding capacity. J Steroid Biochem Mol Biol. (1994) 50:175-9. doi: 10.1016/0960-0760(94)90026-4

49. Kvorning T, Andersen M, Brixen K, Madsen K. Suppression of endogenous testosterone production attenuates the response to strength training: a randomized, placebo-controlled, and blinded intervention study. Am J Physiol Endocrinol Metab. (2006) 291:E1325-32. doi: 10.1152/ajpendo.00143.2006

50. Gelmann EP. Molecular biology of the androgen receptor. J Clin Oncol. (2002) 20:3001-15. doi: 10.1200/JCO.2002.10.018

51. Nitsche EM, Hiort O. The molecular basis of androgen insensitivity. Horm Res. (2000) 54:327-33. doi: 10.1159/000053282

52. Wilson CM, McPhaul MJ. A and B forms of the androgen receptor are expressed in a variety of human tissues. Mol Cell Endocrinol. (1996) 120:517. doi: 10.1016/0303-7207(96)03819-1

53. Zhou ZX, Wong CI, Sar M, Wilson EM. The androgen receptor: an overview. Recent Prog Horm Res. (1994) 49:24974. doi: 10.1016/B978-0-12-571149-4.50017-9

54. MacLean HE, Warne GL, Zajac JD. Localization of functional domains in the androgen receptor. J Steroid Biochem Mol Biol. (1997) 62:23342. doi: 10.1016/S0960-0760(97)00049-6

55. Wong HY, Burghoorn JA, Van Leeuwen M, De Ruiter PE, Schippers E, Blok LJ, et al. Phosphorylation of androgen receptor isoforms. Biochem J. (2004) 383:267-76. doi: 10.1042/BJ20040683

56. Kim HJ, Lee WJ. Ligand-independent activation of the androgen receptor by insulin-like growth factor-I and the role of the MAPK pathway in skeletal muscle cells. Mol Cells. (2009) 28:589-93. doi: 10.1007/s10059-009-0167-z

57. Nicoll JX, Fry AC, Mosier EM. Sex-based differences in resting MAPK, androgen, and glucocorticoid receptor phosphorylation in human skeletal muscle. Steroids. (2019) 141:23-9. doi: 10.1016/j.steroids.2018.11.004

58. Eder IE, Culig Z, Putz T, Nessler-Menardi C, Bartsch G, Klocker H. Molecular biology of the androgen receptor: from molecular understanding to the clinic. Eur Urol. (2001) 40:241-51. doi: 10.1159/000049782

59. Kemppainen JA, Langley E, Wong CI, Bobseine K, Kelce WR, Wilson EM. Distinguishing androgen receptor agonists and antagonists: distinct mechanisms of activation by medroxyprogesterone acetate and dihydrotestosterone. Mol Endocrinol. (1999) 13:44054. doi: 10.1210/mend.13.3.0255

60. Zhou ZX, Lane MV, Kemppainen JA, French FS, Wilson EM. Specificity of ligand-dependent androgen receptor stabilization: receptor domain interactions influence ligand dissociation and receptor stability. Mol Endocrinol. (1995) 9:208-18. doi: 10.1210/mend.9.2.7776971

61. van de Wijngaart DJ, Dubbink HJ, van Royen ME, Trapman J, Jenster G. Androgen receptor coregulators: recruitment via the coactivator binding groove. Mol Cell Endocrinol. (2012) 352:57-69. doi: 10.1016/j.mce.2011.08.007

62. Narayanan R, Jiang J, Gusev Y, Jones A, Kearbey JD, Miller DD, Schmittgen TD, Dalton JT. MicroRNAs are mediators of androgen action in prostate and muscle. PLoS ONE. (2010) 5:e13637. doi: 10.1371/journal.pone.0013637

63. Foley C, Mitsiades N. Moving beyond the androgen receptor (AR): targeting AR-interacting proteins to treat prostate cancer. Horm Cancer. (2016) 7:84103. doi: $10.1007 / \mathrm{s} 12672-015-0239-9$

64. Jenster G, Spencer TE, Burcin MM, Tsai SY, Tsai MJ, O’Malley BW. Steroid receptor induction of gene transcription: a two-step model. Proc Natl Acad Sci USA. (1997) 94:7879-84. doi: 10.1073/pnas.94.15.7879

65. Reid J, Murray I, Watt K, Betney R, McEwan IJ. The androgen receptor interacts with multiple regions of the large subunit of general transcription factor TFIIF. J Biol Chem. (2002) 277:41247-53. doi: 10.1074/jbc.M205220200

66. Tirabassi G, Cignarelli A, Perrini S, Delli Muti N, Furlani G, Gallo M, et al. Influence of CAG repeat polymorphism on the targets of testosterone action. Int J Endocrinol. (2015) 2015:298107. doi: 10.1155/2015/298107

67. De Naeyer H, Bogaert V, De Spaey A, Roef G, Vandewalle S, Derave W, et al. Genetic variations in the androgen receptor are associated with steroid concentrations and anthropometrics but not with muscle mass in healthy young men. PLoS ONE. (2014) 9:e86235. doi: 10.1371/journal.pone.00 86235
68. Folland JP, Mc Cauley TM, Phypers C, Hanson B, Mastana SS. The relationship of testosterone and AR CAG repeat genotype with knee extensor muscle function of young and older men. Exp Gerontol. (2012) 47:43743. doi: 10.1016/j.exger.2012.03.013

69. Simmons ZL, Roney JR. Variation in CAG repeat length of the androgen receptor gene predicts variables associated with intrasexual competitiveness in human males. Horm Behav. (2011) 60:306-12. doi: 10.1016/j.yhbeh.2011.06.006

70. Walsh S, Zmuda JM, Cauley JA, Shea PR, Metter EJ, Hurley $\mathrm{BF}$, et al. Androgen receptor CAG repeat polymorphism is associated with fat-free mass in men. J Appl Physiol. (2005) 98:132-7. doi: 10.1152/japplphysiol.00537.2004

71. Nielsen TL, Hagen C, Wraae K, Bathum L, Larsen R, Brixen K, et al. The impact of the CAG repeat polymorphism of the androgen receptor gene on muscle and adipose tissues in 20-29-year-old Danish men: odense androgen study. Eur J Endocrinol. (2010) 162:795-804. doi: 10.1530/EJE-09-0763

72. Kadi F, Bonnerud P, Eriksson A, Thornell LE. The expression of androgen receptors in human neck and limb muscles: effects of training and selfadministration of androgenic-anabolic steroids. Histochem Cell Biol. (2000) 113:25-9. doi: 10.1007/s004180050003

73. Ratamess NA, Kraemer WJ, Volek JS, Maresh CM, Vanheest JL, Sharman MJ, et al. Androgen receptor content following heavy resistance exercise in men. $J$ Steroid Biochem Mol Biol. (2005) 93:35-42. doi: 10.1016/j.jsbmb.2004.10.019

74. Bamman MM, Shipp JR, Jiang J, Gower BA, Hunter GR, Goodman A, et al. Mechanical load increases muscle IGF-I and androgen receptor mRNA concentrations in humans. Am J Physiol Endocrinol Metab. (2001) 280:E38390. doi: 10.1152/ajpendo.2001.280.3.E383

75. Willoughby DS, Taylor L. Effects of sequential bouts of resistance exercise on androgen receptor expression. Med Sci Sports Exerc. (2004) 36:1499506. doi: 10.1249/01.MSS.0000139795.83030.D1

76. Vingren JL, Kraemer WJ, Hatfield DL, Volek JS, Ratamess NA, Anderson JM, et al. Effect of resistance exercise on muscle steroid receptor protein content in strength-trained men and women. Steroids. (2009) 74:10339. doi: 10.1016/j.steroids.2009.08.002

77. Kraemer WJ, Spiering BA, Volek JS, Ratamess NA, Sharman MJ, Rubin MR, et al. Androgenic responses to resistance exercise: effects of feeding and L-carnitine. Med Sci Sports Exerc. (2006) 38:128896. doi: 10.1249/01.mss.0000227314.85728.35

78. West DW, Burd NA, Churchward-Venne TA, Camera DM, Mitchell CJ, Baker SK, et al. Sex-based comparisons of myofibrillar protein synthesis after resistance exercise in the fed state. J Appl Physiol (1985). (2012) 112:180513. doi: 10.1152 /japplphysiol.00170.2012

79. Hulmi JJ, Ahtiainen JP, Selanne H, Volek JS, Hakkinen K, Kovanen V, et al. Androgen receptors and testosterone in men-effects of protein ingestion, resistance exercise and fiber type. J Steroid Biochem Mol Biol. (2008) 110:1307. doi: 10.1016/j.jsbmb.2008.03.030

80. Ahtiainen JP, Hulmi JJ, Kraemer WJ, Lehti M, Nyman K, Selanne H, et al. Heavy resistance exercise training and skeletal muscle androgen receptor expression in younger and older men. Steroids. (2011) 76:18392. doi: $10.1016 /$ j.steroids. 2010.10 .012

81. Ahtiainen JP, Lehti M, Hulmi JJ, Kraemer WJ, Alen M, Nyman $\mathrm{K}$, et al. Recovery after heavy resistance exercise and skeletal muscle androgen receptor and insulin-like growth factor-I isoform expression in strength trained men. J Strength Cond Res. (2011) 25:767-77. doi: 10.1519/JSC.0b013e318202e449

82. Ahtiainen JP, Nyman K, Huhtaniemi I, Parviainen T, Helste M, Rannikko A, et al. Effects of resistance training on testosterone metabolism in younger and older men. Exp Gerontol. (2015) 69:148-58. doi: 10.1016/j.exger.2015.06.010

83. Nilsen TS, Thorsen L, Fossa SD, Wiig M, Kirkegaard C, Skovlund E, et al. Effects of strength training on muscle cellular outcomes in prostate cancer patients on androgen deprivation therapy. Scand J Med Sci Sports. (2016) 26:1026-35. doi: $10.1111 /$ sms. 12543

84. Mitchell CJ, Churchward-Venne TA, Bellamy L, Parise G, Baker SK, Phillips SM. Muscular and systemic correlates of resistance training-induced muscle hypertrophy. PLoS ONE. (2013) 8:e78636. doi: 10.1371/journal.pone.0078636

85. Mobley CB, Haun CT, Roberson PA, Mumford PW, Kephart WC, Romero $\mathrm{MA}$, et al. Biomarkers associated with low, moderate, and high vastus 
lateralis muscle hypertrophy following 12 weeks of resistance training. PLoS ONE. (2018) 13:e0195203. doi: 10.1371/journal.pone.0195203

86. Haun CT, Vann CG, Mobley CB, Osburn SC, Mumford PW, Roberson $\mathrm{PA}$, et al. Pre-training skeletal muscle fiber size and predominant fiber type best predict hypertrophic responses to 6 weeks of resistance training in previously trained young men. Front Physiol. (2019) 10:297. doi: 10.3389/fphys.2019.00297

87. Roberts MD, Dalbo VJ, Hassell SE, Kerksick CM. The expression of androgen-regulated genes before and after a resistance exercise bout in younger and older men. J Strength Cond Res. (2009) 23:10607. doi: 10.1519/JSC.0b013e3181a59bdd

88. Brook MS, Wilkinson DJ, Mitchell WK, Lund JN, Phillips BE, Szewczyk $\mathrm{NJ}$, et al. Synchronous deficits in cumulative muscle protein synthesis and ribosomal biogenesis underlie age-related anabolic resistance to exercise in humans. J Physiol. (2016) 594:7399-417. doi: 10.1113/JP272857

89. Grad I, Picard D. The glucocorticoid responses are shaped by molecular chaperones. Mol Cell Endocrinol. (2007) 275:212. doi: $10.1016 /$ j.mce.2007.05.018

90. Levin I, Sittenfield MJ. The value of the "Hormone" Theory of the Causation of new Growth. J Med Res. (1911) 25:259-61.

91. Papkoff H, Li CH, Liuwk. The isolation and characterization of growth hormone from porcine pituitaries. Arch Biochem Biophys. (1962) 96:21625. doi: 10.1016/0003-9861(62)90401-0

92. Greenspan FS, Li CH, Simpson ME, Evans HM. Bioassay of hypophyseal growth hormone; the tibia test. Endocrinology. (1949) 45:455-63. doi: 10.1210/endo-45-5-455

93. Li CH. Pituitary growth hormone as a metabolic hormone. Science. (1956) 123:617-8. doi: 10.1126/science.123.3198.617

94. Sutton J, Young JD, Lazarus L, Hickie JB, Maksvytis J. Hormonal changes during exercise. Lancet. (1968) 2:13045. doi: 10.1016/S0140-6736(68)91806-0

95. Ellis S, Vodian MA, Grindeland RE. Studies on the bioassayable growth hormone-like activity of plasma. Recent Prog Horm Res. (1978) 34:21338. doi: 10.1016/B978-0-12-571134-0.50009-0

96. Hymer WC, Kennett MJ, Maji SK, Gosselink KL, McCall GE, Grindeland RE, et al. Bioactive growth hormone in humans: controversies, complexities and concepts. Growth Horm IGF Res. (2019) 50:9-22. doi: 10.1016/j.ghir.2019.11.003

97. Roswall EC, Mukku VR, Chen AB, Hoff EH, Chu H, McKay PA, et al. Novel assays based on human growth hormone receptor as alternatives to the rat weight gain bioassay for recombinant human growth hormone. Biologicals. (1996) 24:25-39. doi: 10.1006/biol.1996.0003

98. Baumann GP. Growth hormone isoforms. Growth Horm IGF Res. (2009) 19:333-40. doi: 10.1016/j.ghir.2009.04.011

99. Lewis UJ. Growth hormone what is it and what does it do? Trends Endocrinol Metab. (1992) 3:117-21. doi: 10.1016/1043-2760(92)90099-M

100. Bristow AF, Jeffcoate SL. Analysis of therapeutic growth hormone preparations: report of an interlaboratory collaborative study on growth hormone assay methodologies. Biologicals. (1992) 20:221-31. doi: 10.1016/S1045-1056(05)80041-7

101. Rowlinson SW, Waters MJ, Lewis UJ, Barnard R. Human growth hormone fragments 1-43 and 44-191: in vitro somatogenic activity and receptor binding characteristics in human and nonprimate systems. Endocrinology. (1996) 137:90-5. doi: 10.1210/endo.137.1.85 36647

102. McCall GE, Gosselink KL, Bigbee AJ, Roy RR, Grindeland RE, Edgerton VR. Muscle afferent-pituitary axis: a novel pathway for modulating the secretion of a pituitary growth factor. Exerc Sport Sci Rev. (2001) 29:1649. doi: 10.1097/00003677-200110000-00006

103. McCall GE, Goulet C, Roy RR, Grindeland RE, Boorman GI, Bigbee AJ, et al. Spaceflight suppresses exercise-induced release of bioassayable growth hormone. J Appl Physiol. (1999) 87:1207-12. doi: 10.1152/jappl.1999.87.3.1207

104. McCall GE, Goulet C, Grindeland RE, Hodgson JA, Bigbee AJ, Edgerton VR. Bed rest suppresses bioassayable growth hormone release in response to muscle activity. J Appl Physiol. (1997) 83:2086-90. doi: 10.1152/jappl.1997.83.6.2086
105. McCall GE, Grindeland RE, Roy RR, Edgerton VR. Muscle afferent activity modulates bioassayable growth hormone in human plasma. J Appl Physiol. (2000) 89:1137-41. doi: 10.1152/jappl.2000.89.3.1137

106. Hymer WC, Kraemer WJ, Nindl BC, Marx JO, Benson DE, Welsch JR, et al. Characteristics of circulating growth hormone in women after acute heavy resistance exercise. Am J Physiol Endocrinol Metab. (2001) 281:E87887. doi: 10.1152/ajpendo.2001.281.4.E878

107. Strasburger CJ, Wu Z, Pflaum CD, Dressendorfer RA. Immunofunctional assay of human growth hormone (hGH) in serum: a possible consensus for quantitative hGH measurement. J Clin Endocrinol Metab. (1996) 81:261320. doi: $10.1210 /$ jc.81.7.2613

108. Kraemer WJ, Rubin MR, Hakkinen K, Nindl BC, Marx JO, Volek JS, et al. Influence of muscle strength and total work on exercise-induced plasma growth hormone isoforms in women. J Sci Med Sport. (2003) 6:295306. doi: 10.1016/S1440-2440(03)80023-3

109. Thomas GA, Kraemer WJ, Kennett MJ, Comstock BA, Maresh CM, Denegar $\mathrm{CR}$, et al. Immunoreactive and bioactive growth hormone responses to resistance exercise in men who are lean or obese. J Appl Physiol. (2011) 111:465-72. doi: 10.1152/japplphysiol.00157.2011

110. Gordon SE, Kraemer WJ, Looney DP, Flanagan SD, Comstock BA, Hymer WC. The influence of age and exercise modality on growth hormone bioactivity in women. Growth Horm IGF Res. (2014) 24:95103. doi: 10.1016/j.ghir.2014.03.005

111. Kraemer WJ, Nindl BC, Marx JO, Gotshalk LA, Bush JA, Welsch JR, et al. Chronic resistance training in women potentiates growth hormone in vivo bioactivity: characterization of molecular mass variants. Am J Physiol Endocrinol Metab. (2006) 291:E1177-87. doi: 10.1152/ajpendo.00042.2006

112. Kraemer WJ, Kennett MJ, Mastro AM, McCarter RJ, Rogers CJ, DuPont WH, et al. Bioactive growth hormone in older men and women: it's relationship to immune markers and healthspan. Growth Horm IGF Res. (2017) 34:4554. doi: 10.1016/j.ghir.2017.05.002

113. Grindeland RE, Kraemer WJ, Hymer WC. Two types of rat pituitary somatotrophs secrete growth hormone with different biological and immunological profiles. Growth Horm IGF Res. (2017) 36:52-6. doi: 10.1016/j.ghir.2017.09.001

114. Cheung LYM, George AS, McGee SR, Daly AZ, Brinkmeier ML, Ellsworth BS, et al. Single-Cell RNA sequencing reveals novel markers of male pituitary stem cells and hormone-producing cell types. Endocrinology. (2018) 159:3910-24. doi: 10.1210/en.2018-00750

115. Fletcher PA, Smiljanic K, Maso Previde R, Iben JR, Li T, Rokic MB, et al. Cell type- and sex-dependent transcriptome profiles of rat anterior pituitary cells. Front Endocrinol. (2019) 10:623. doi: 10.3389/fendo.2019.00623

116. Slaby F, Farquhar MG. Isolation of rat somatotroph and mammotroph secretory granules by equilibrium density centrifugation in a linear metrizamide gradient. Mol Cell Endocrinol. (1980) 18:21-32. doi: 10.1016/0303-7207(80)90004-0

117. Slaby F, Farquhar MG. Characterization of rat somatotroph and mammotroph secretory granules. Presence of sulfated molecules. Mol Cell Endocrinol. (1980) 18:33-48. doi: 10.1016/0303-7207(80)90005-2

118. Hymer WC, Mc SW. Isolation of rat pituitary granules and the study of their biochemical properties and hormonal activities. J Cell Biol. (1963) 17:67-86. doi: 10.1083/jcb.17.1.67

119. Cunningham BC, Mulkerrin MG, Wells JA. Dimerization of human growth hormone by zinc. Science. (1991) 253:545-8. doi: 10.1126/science.1907025

120. Sobota JA, Ferraro F, Back N, Eipper BA, Mains RE. Not all secretory granules are created equal: partitioning of soluble content proteins. Mol Biol Cell. (2006) 17:5038-52. doi: 10.1091/mbc.e06-07-0626

121. Lorenson MY, Robson DL, Jacobs LS. Divalent cation inhibition of hormone release from isolated adenohypophysial secretory granules. J Biol Chem. (1983) 258:8618-22.

122. Dannies P. Manipulating the reversible aggregation of protein hormones in secretory granules: potential impact on biopharmaceutical development. BioDrugs. (2003) 17:315-24. doi: 10.2165/00063030-20031705000002

123. Farrington M, Hymer WC. Growth hormone aggregates in the rat adenohypophysis. Endocrinology. (1990) 126:16308. doi: 10.1210/endo-126-3-1630 
124. Maji SK, Perrin MH, Sawaya MR, Jessberger S, Vadodaria K, Rissman RA, et al. Functional amyloids as natural storage of peptide hormones in pituitary secretory granules. Science. (2009) 325:328-32. doi: 10.1126/science.1173155

125. Jacob RS, Das S, Ghosh S, Anoop A, Jha NN, Khan T, et al. Amyloid formation of growth hormone in presence of zinc: relevance to its storage in secretory granules. Sci Rep. (2016) 6:23370. doi: 10.1038/srep23370

126. Mehra S, Sahay S, Maji SK. $\alpha$-Synuclein misfolding and aggregation: implications in Parkinson's disease pathogenesis. Biochim Biophys Acta Proteins Proteom. (2019) 1867:890-908. doi: 10.1016/j.bbapap.2019.03.001

127. Landreh M, Rising A, Presto J, Jornvall H, Johansson J. Specific chaperones and regulatory domains in control of amyloid formation. J Biol Chem. (2015) 290:26430-6. doi: 10.1074/jbc.R115.653097

128. Frottin F, Schueder F, Tiwary S, Gupta R, Korner R, Schlichthaerle T, et al. The nucleolus functions as a phase-separated protein quality control compartment. Science. (2019) 365:342-7. doi: 10.1126/science.aaw9157

129. Mediani L, Guillen-Boixet J, Vinet J, Franzmann TM, Bigi I, Mateju D, et al. Defective ribosomal products challenge nuclear function by impairing nuclear condensate dynamics and immobilizing ubiquitin. EMBO J. (2019) 38:e101341. doi: 10.15252/embj.2018101341

130. Chakrabarti O, Rane NS, Hegde RS. Cytosolic aggregates perturb the degradation of nontranslocated secretory and membrane proteins. Mol Biol Cell. (2011) 22:1625-37. doi: 10.1091/mbc.e10-07-0638

131. Alberti S, Carra S. Nucleolus: a liquid droplet compartment for misbehaving proteins. Curr Biol. (2019) 29:R930-2. doi: 10.1016/j.cub.2019.08.013

132. Hartley LH. Growth hormone and catecholamine response to exercise in relation to physical training. Med Sci Sports. (1975) 7:34-6. doi: 10.1249/00005768-197500710-00007

133. Shephard RJ, Sidney KH. Effects of physical exercise on plasma growth hormone and cortisol levels in human subjects. Exerc Sport Sci Rev. (1975) 3:1-30. doi: 10.1249/00003677-197500030-00004

134. Kraemer WJ. Endocrine responses to resistance exercise. Med Sci Sports Exerc. (1988) 20:S152-7. doi: 10.1249/00005768-198810001-00011

135. Macintyre JG. Growth hormone and athletes. Sports Med. (1987) 4:12942. doi: 10.2165/00007256-198704020-00004

136. Vanhelder WP, Radomski MW, Goode RC. Growth hormone responses during intermittent weight lifting exercise in men. Eur J Appl Physiol Occup Physiol. (1984) 53:31-4. doi: 10.1007/BF00964686

137. Baumann G. Growth hormone binding protein. The soluble growth hormone receptor. Minerva Endocrinol. (2002) 27:265-76.

138. Baumann G. Growth hormone binding protein 2001. J Pediatr Endocrinol Metab. (2001) 14:355-75. doi: 10.1515/JPEM.2001.14.4.355

139. Junnila RK, Kopchick JJ. Significance of the disulphide bonds of human growth hormone. Endokrynol Pol. (2013) 64:3005. doi: 10.5603/EP.2013.0009

140. Rubin MR, Kraemer WJ, Maresh CM, Volek JS, Ratamess NA, Vanheest JL, et al. High-affinity growth hormone binding protein and acute heavy resistance exercise. Med Sci Sports Exerc. (2005) 37:395-403. doi: 10.1249/01.MSS.0000155402.9 3987.C0

141. Gordon SE, Kraemer WJ, Vos NH, Lynch JM, Knuttgen HG. Effect of acid-base balance on the growth hormone response to acute high-intensity cycle exercise. J Appl Physiol. (1994) 76:821-9. doi: 10.1152/jappl.1994.7 6.2.821

142. Weltman JY, Seip RL, Weltman A, Snead D, Evans WS, Veldhuis $\mathrm{JD}$, et al. Release of luteinizing hormone and growth hormone after recovery from maximal exercise. J Appl Physiol. (1990) 69:196-200. doi: 10.1152/jappl.1990.69.1.196

143. Hartman ML, Iranmanesh A, Thorner MO, Veldhuis JD. Evaluation of pulsatile patterns of growth hormone release in humans: a brief review. Am J Hum Biol. (1993) 5:603-14. doi: 10.1002/ajhb.1310050603

144. Kraemer WJ, Marchitelli L, Gordon SE, Harman E, Dziados JE, Mello R, et al. Hormonal and growth factor responses to heavy resistance exercise protocols. J Appl Physiol. (1990) 69:1442-50. doi: 10.1152/jappl.1990.69.4.1442

145. Kraemer WJ, Fleck SJ, Dziados JE, Harman EA, Marchitelli LJ, Gordon $\mathrm{SE}$, et al. Changes in hormonal concentrations after different heavyresistance exercise protocols in women. J Appl Physiol. (1993) 75:594604. doi: 10.21236/ADA272663
146. Nindl BC. Exercise modulation of growth hormone isoforms: current knowledge and future directions for the exercise endocrinologist. Br J Sports Med. (2007) 41:346-8; discussion 348. doi: 10.1136/bjsm.2006.028951

147. Nindl BC, Hymer WC, Deaver DR, Kraemer WJ. Growth hormone pulsatility profile characteristics following acute heavy resistance exercise. $J$ Appl Physiol. (2001) 91:163-72. doi: 10.1152/jappl.2001.91.1.163

148. Nindl BC, Kraemer WJ, Marx JO, Arciero PJ, Dohi K, Kellogg $\mathrm{MD}$, et al. Overnight responses of the circulating IGF-I system after acute, heavy-resistance exercise. J Appl Physiol. (2001) 90:1319-26. doi: 10.1152/jappl.2001.90.4.1319

149. Nindl BC, Urso ML, Pierce JR, Scofield DE, Barnes BR, Kraemer WJ, et al. IGF-I measurement across blood, interstitial fluid, and muscle biocompartments following explosive, highpower exercise. Am J Physiol Regul Integr Comp Physiol. (2012) 303:R1080-9. doi: 10.1152/ajpregu.00275.2012

150. Florini JR, Ewton DZ, Coolican SA. Growth hormone and the insulinlike growth factor system in myogenesis. Endocr Rev. (1996) 17:481517. doi: 10.1210/edrv-17-5-481

151. Harridge SD. Plasticity of human skeletal muscle: gene expression to in vivo function. Exp Physiol. (2007) 92:78397. doi: 10.1113/expphysiol.2006.036525

152. Adams GR. Role of insulin-like growth factor-I in the regulation of skeletal muscle adaptation to increased loading. Exerc Sport Sci Rev. (1998) 26:3160. doi: 10.1249/00003677-199800260-00004

153. Harridge SD, Velloso CP. IGF-I and GH: potential use in gene doping. Growth Horm IGF Res. (2009) 19:378-82. doi: 10.1016/j.ghir.2009.04.016

154. Ascenzi F, Barberi L, Dobrowolny G, Villa Nova Bacurau A, Nicoletti C, Rizzuto E, et al. Effects of IGF-1 isoforms on muscle growth and sarcopenia. Aging Cell. (2019) 18:e12954. doi: 10.1111/acel.12954

155. Nindl BC, Pierce JR. Insulin-like growth factor I as a biomarker of health, fitness, and training status. Med Sci Sports Exerc. (2010) 42:3949. doi: 10.1249/MSS.0b013e3181b07c4d

156. Petrella JK, Kim JS, Mayhew DL, Cross JM, Bamman MM. Potent myofiber hypertrophy during resistance training in humans is associated with satellite cell-mediated myonuclear addition: a cluster analysis. J Appl Physiol. (2008) 104:1736-42. doi: 10.1152/japplphysiol.01215.2007

157. Philippou A, Halapas A, Maridaki M, Koutsilieris M. Type I insulinlike growth factor receptor signaling in skeletal muscle regeneration and hypertrophy. J Musculoskelet Neuronal Interact. (2007) 7:208-18.

158. Wilborn CD, Taylor LW, Greenwood M, Kreider RB, Willoughby DS. Effects of different intensities of resistance exercise on regulators of myogenesis. $J$ Strength Cond Res. (2009) 23:2179-87. doi: 10.1519/JSC.0b013e3181bab493

159. Goldspink G, Wessner B, Tschan H, Bachl N. Growth factors, muscle function, and doping. Endocrinol Metab Clin North Am. (2010) 39:16981. doi: 10.1016/j.ecl.2009.11.001

160. Hakuno F, Takahashi SI. IGF1 receptor signaling pathways. J Mol Endocrinol. (2018) 61:T69-86. doi: 10.1530/JME-17-0311

161. Nissley SP, Haskell JF, Sasaki N, De Vroede MA, Rechler MM. Insulin-like growth factor receptors. J Cell Sci Suppl. (1985) 3:3951. doi: 10.1242/jcs.1985.Supplement_3.5

162. Gonzalez AM, Hoffman JR, Townsend JR, Jajtner AR, Boone CH, Beyer $\mathrm{KS}$, et al. Intramuscular anabolic signaling and endocrine response following high volume and high intensity resistance exercise protocols in trained men. Physiol Rep. (2015) 3:e12466. doi: 10.14814/phy2.12466

163. Crossland H, Kazi AA, Lang CH, Timmons JA, Pierre P, Wilkinson DJ, et al. Focal adhesion kinase is required for IGF-I-mediated growth of skeletal muscle cells via a TSC2/mTOR/S6K1-associated pathway. Am J Physiol Endocrinol Metab. (2013) 305:E183-93. doi: 10.1152/ajpendo.00541.2012

164. Barclay RD, Burd NA, Tyler C, Tillin NA, Mackenzie RW. The role of the IGF-1 signaling cascade in muscle protein synthesis and anabolic resistance in aging skeletal muscle. Front Nutr. (2019) 6:146. doi: 10.3389/fnut.2019.00146

165. Sheffield-Moore M, Urban RJ. An overview of the endocrinology of skeletal muscle. Trends Endocrinol Metab. (2004) 15:1105. doi: 10.1016/j.tem.2004.02.009

166. Chan S, Debono M. Replication of cortisol circadian rhythm: new advances in hydrocortisone replacement therapy. Ther Adv Endocrinol Metab. (2010) 1:129-38. doi: 10.1177/2042018810380214 
167. Hsu SC, DeFranco DB. Selectivity of cell cycle regulation of glucocorticoid receptor function. J Biol Chem. (1995) 270:335964. doi: 10.1074/jbc.270.7.3359

168. Kino $\mathrm{T}, \mathrm{Su}$ YA, Chrousos GP. Human glucocorticoid receptor isoform beta: recent understanding of its potential implications in physiology and pathophysiology. Cell Mol Life Sci. (2009) 66:3435-48. doi: 10.1007/s00018-009-0098-z

169. Lamberts SW, Huizenga AT, de Lange P, de Jong FH, Koper JW. Clinical aspects of glucocorticoid sensitivity. Steroids. (1996) 61:15760. doi: 10.1016/0039-128X(96)00005-0

170. Polman JA, Hunter RG, Speksnijder N, van den Oever JM, Korobko OB, McEwen BS, et al. Glucocorticoids modulate the mTOR pathway in the hippocampus: differential effects depending on stress history. Endocrinology. (2012) 153:4317-27. doi: 10.1210/en.2012-1255

171. Munck A, Guyre PM, Holbrook NJ. Physiological functions of glucocorticoids in stress and their relation to pharmacological actions. Endocr Rev. (1984) 5:25-44. doi: 10.1210/edrv-5-1-25

172. Duclos M, Gouarne C, Bonnemaison D. Acute and chronic effects of exercise on tissue sensitivity to glucocorticoids. J Appl Physiol. (2003) 94:86975. doi: 10.1152/japplphysiol.00108.2002

173. Kraemer WJ, Patton JF, Gordon SE, Harman EA, Deschenes MR, Reynolds $\mathrm{K}$, et al. Compatibility of high-intensity strength and endurance training on hormonal and skeletal muscle adaptations. J Appl Physiol. (1995) 78:97689. doi: 10.1152/jappl.1995.78.3.976

174. Duclos M, Minkhar M, Sarrieau A, Bonnemaison D, Manier G, Mormede P. Reversibility of endurance training-induced changes on glucocorticoid sensitivity of monocytes by an acute exercise. Clin Endocrinol. (1999) 51:74956. doi: 10.1046/j.1365-2265.1999.00878.x

175. Gouarne C, Groussard C, Gratas-Delamarche A, Delamarche P, Duclos M. Overnight urinary cortisol and cortisone add new insights into adaptation to training. Med Sci Sports Exerc. (2005) 37:1157-67. doi: 10.1249/01.mss.0000170099.10038.3b

176. McCarthy JJ, Esser KA. Anabolic and catabolic pathways regulating skeletal muscle mass. Curr Opin Clin Nutr Metab Care. (2010) 13:2305. doi: 10.1097/MCO.0b013e32833781b5

177. Chapman K, Holmes M, Seckl J. 11ß-hydroxysteroid dehydrogenases: intracellular gate-keepers of tissue glucocorticoid action. Physiol Rev. (2013) 93:1139-206. doi: 10.1152/physrev.00020.2012

178. Stewart PM, Krozowski ZS. 11ß-Hydroxysteroid dehydrogenase. Vitam Horm. (1999) 57:249-324. doi: 10.1016/S0083-6729(08)60646-9

179. Whorwood CB, Donovan SJ, Wood PJ, Phillips DI. Regulation of glucocorticoid receptor alpha and beta isoforms and type I 11betahydroxysteroid dehydrogenase expression in human skeletal muscle cells:a key role in the pathogenesis of insulin resistance? J Clin Endocrinol Metab. (2001) 86:2296-308. doi: 10.1210/jcem.86.5.7503

180. Whorwood CB, Donovan SJ, Flanagan D, Phillips DI, Byrne CD. Increased glucocorticoid receptor expression in human skeletal muscle cells may contribute to the pathogenesis of the metabolic syndrome. Diabetes. (2002) 51:1066-75. doi: 10.2337/diabetes.51.4.1066

181. Andrews RC, Walker BR. Glucocorticoids and insulin resistance: old hormones, new targets. Clin Sci. (1999) 96:513-23. doi: 10.1042/cs0960513

182. Walker BR, Phillips DI, Noon JP, Panarelli M, Andrew R, Edwards HV, et al. Increased glucocorticoid activity in men with cardiovascular risk factors. Hypertension. (1998) 31:891-5. doi: 10.1161/01.HYP.31.4.891

183. Kadmiel M, Cidlowski JA. Glucocorticoid receptor signaling in health and disease. Trends Pharmacol Sci. (2013) 34:51830. doi: 10.1016/j.tips.2013.07.003

184. Meijsing SH, Pufall MA, So AY, Bates DL, Chen L, Yamamoto KR. DNA binding site sequence directs glucocorticoid receptor structure and activity. Science. (2009) 324:407-10. doi: 10.1126/science.1164265

185. Kuo T, Harris CA, Wang JC. Metabolic functions of glucocorticoid receptor in skeletal muscle. Mol Cell Endocrinol. (2013) 380:79-88. doi: 10.1016/j.mce.2013.03.003

186. Tanaka H, Shimizu N, Yoshikawa N. Role of skeletal muscle glucocorticoid receptor in systemic energy homeostasis. Exp Cell Res. (2017) 360:246. doi: 10.1016/j.yexcr.2017.03.049

187. Uhlenhaut NH, Barish GD, Yu RT, Downes M, Karunasiri M, Liddle C, et al. Insights into negative regulation by the glucocorticoid receptor from genome-wide profiling of inflammatory cistromes. Mol Cell. (2013) 49:15871. doi: 10.1016/j.molcel.2012.10.013

188. Biddie SC, John S, Sabo PJ, Thurman RE, Johnson TA, Schiltz RL, et al. Transcription factor AP1 potentiates chromatin accessibility and glucocorticoid receptor binding. Mol Cell. (2011) 43:145-55. doi: 10.1016/j.molcel.2011.06.016

189. Grontved L, John S, Baek S, Liu Y, Buckley JR, Vinson C, et al. C/EBP maintains chromatin accessibility in liver and facilitates glucocorticoid receptor recruitment to steroid response elements. EMBO J. (2013) 32:156883. doi: $10.1038 /$ emboj.2013.106

190. John S, Sabo PJ, Thurman RE, Sung MH, Biddie SC, Johnson TA, et al. Chromatin accessibility pre-determines glucocorticoid receptor binding patterns. Nat Genet. (2011) 43:264-8. doi: 10.1038/ng.759

191. Penner G, Gang G, Sun X, Wray C, Hasselgren PO. C/EBP DNAbinding activity is upregulated by a glucocorticoid-dependent mechanism in septic muscle. Am J Physiol Regul Integr Comp Physiol. (2002) 282:R43944. doi: 10.1152/ajpregu.00512.2001

192. Boncompagni S, Arthurton L, Akujuru E, Pearson T, Steverding D, Protasi F, et al. Membrane glucocorticoid receptors are localised in the extracellular matrix and signal through the MAPK pathway in mammalian skeletal muscle fibres. J Physiol. (2015) 593:2679-92. doi: 10.1113/JP270502

193. Perez MH, Cormack J, Mallinson D, Mutungi G. A membrane glucocorticoid receptor mediates the rapid/non-genomic actions of glucocorticoids in mammalian skeletal muscle fibres. J Physiol. (2013) 591:517185. doi: 10.1113/jphysiol.2013.256586

194. Francke U, Foellmer BE. The glucocorticoid receptor gene is in 5q31-q32 [corrected]. Genomics. (1989) 4:610-2. doi: 10.1016/0888-7543(89)90287-5

195. Oakley RH, Sar M, Cidlowski JA. The human glucocorticoid receptor beta isoform. Expression, biochemical properties, and putative function. J Biol Chem. (1996) 271:9550-9. doi: 10.1074/jbc.271.16.9550

196. Hinds TD Jr, Ramakrishnan S, Cash HA, Stechschulte LA, Heinrich G, Najjar SM, et al. Discovery of glucocorticoid receptor-beta in mice with a role in metabolism. Mol Endocrinol. (2010) 24:1715-27. doi: 10.1210/me.2009-0411

197. Pujols L, Mullol J, Roca-Ferrer J, Torrego A, Xaubet A, Cidlowski JA, et al. Expression of glucocorticoid receptor alpha- and beta-isoforms in human cells and tissues. Am J Physiol Cell Physiol. (2002) 283:C132431. doi: 10.1152/ajpcell.00363.2001

198. Leventhal SM, Lim D, Green TL, Cantrell AE, Cho K, Greenhalgh DG. Uncovering a multitude of human glucocorticoid receptor variants: an expansive survey of a single gene. BMC Genet. (2019) 20:16. doi: 10.1186/s12863-019-0718-z

199. Lewis-Tuffin LJ, Cidlowski JA. The physiology of human glucocorticoid receptor beta (hGRbeta) and glucocorticoid resistance. Ann N Y Acad Sci. (2006) 1069:1-9. doi: 10.1196/annals.1351.001

200. Webster JC, Oakley RH, Jewell CM, Cidlowski JA. Proinflammatory cytokines regulate human glucocorticoid receptor gene expression and lead to the accumulation of the dominant negative beta isoform: a mechanism for the generation of glucocorticoid resistance. Proc Natl Acad Sci USA. (2001) 98:6865-70. doi: 10.1073/pnas.121455098

201. Hinds TD, Peck B, Shek E, Stroup S, Hinson J, Arthur S, et al. Overexpression of glucocorticoid receptor $\beta$ enhances myogenesis and reduces catabolic gene expression. Int J Mol Sci. (2016) 17:232. doi: 10.3390/ijms17020232

202. Xu Q, Leung DY, Kisich KO. Serine-arginine-rich protein p30 directs alternative splicing of glucocorticoid receptor pre-mRNA to glucocorticoid receptor beta in neutrophils. J Biol Chem. (2003) 278:27112-8. doi: 10.1074/jbc.M300824200

203. Zhu J, Gong JY, Goodman OB Jr, Cartegni L, Nanus DM, Shen R. Bombesin attenuates pre-mRNA splicing of glucocorticoid receptor by regulating the expression of serine-arginine protein p30c (SRp30c) in prostate cancer cells. Biochim Biophys Acta. (2007) 1773:108794. doi: 10.1016/j.bbamcr.2007.04.016

204. Goecke IA, Alvarez C, Henriquez J, Salas K, Molina ML, Ferreira A, et al. Methotrexate regulates the expression of glucocorticoid receptor alpha and beta isoforms in normal human peripheral mononuclear cells and human lymphocyte cell lines in vitro. Mol Immunol. (2007) 44:211523. doi: 10.1016/j.molimm.2006.07.303

205. Fragala MS, Kraemer WJ, Mastro AM, Denegar CR, Volek JS, Kupchak BR, et al. Glucocorticoid receptor expression on human B cells in response to 
acute heavy resistance exercise. Neuroimmunomodulation. (2011) 18:15664. doi: $10.1159 / 000321633$

206. Bonifazi M, Mencarelli M, Fedele V, Ceccarelli I, Pecorelli A, Grasso G, et al. Glucocorticoid receptor mRNA expression in peripheral blood mononuclear cells in high trained compared to low trained athletes and untrained subjects. J Endocrinol Invest. (2009) 32:816-20. doi: 10.1007/BF03345751

207. Patel R, Williams-Dautovich J, Cummins CL. Minireview: new molecular mediators of glucocorticoid receptor activity in metabolic tissues. Mol Endocrinol. (2014) 28:999-1011. doi: 10.1210/me.2014-1062

208. Qin X, Liu JY, Abdelsayed R, Shi X, Yu JC, Mozaffari MS, et al. The status of glucocorticoid-induced leucine zipper protein in the salivary glands in Sjogren's syndrome: predictive and prognostic potentials. EPMA J. (2015) 7:3. doi: 10.1186/s13167-016-0052-8

209. Schakman O, Kalista S, Barbe C, Loumaye A, Thissen JP. Glucocorticoidinduced skeletal muscle atrophy. Int J Biochem Cell Biol. (2013) 45:216372. doi: 10.1016/j.biocel.2013.05.036

210. Schakman O, Gilson H, Thissen JP. Mechanisms of glucocorticoid-induced myopathy. J Endocrinol. (2008) 197:1-10. doi: 10.1677/JOE-07-0606

211. Sandri M. Protein breakdown in muscle wasting: role of autophagylysosome and ubiquitin-proteasome. Int J Biochem Cell Biol. (2013) 45:21219. doi: 10.1016/j.biocel.2013.04.023

212. Shimizu N, Yoshikawa N, Ito N, Maruyama T, Suzuki Y, Takeda S, et al. Crosstalk between glucocorticoid receptor and nutritional sensor mTOR in skeletal muscle. Cell Metab. (2011) 13:170-82. doi: 10.1016/j.cmet.2011.01.001

213. Seene T, Umnova M, Alev K, Pehme A. Effect of glucocorticoids on contractile apparatus of rat skeletal muscle. J Steroid Biochem. (1988) 29:3137. doi: $10.1016 / 0022-4731(88) 90032-5$

214. Seene T, Viru A. The catabolic effect of glucocorticoids on different types of skeletal muscle fibres and its dependence upon muscle activity and interaction with anabolic steroids. J Steroid Biochem. (1982) 16:34952. doi: 10.1016/0022-4731(82)90190-X

215. Czerwinski SM, Hickson RC. Glucocorticoid receptor activation during exercise in muscle. J Appl Physiol. (1990) 68:161520. doi: 10.1152/jappl.1990.68.4.1615

216. Yudt MR, Jewell CM, Bienstock RJ, Cidlowski JA. Molecular origins for the dominant negative function of human glucocorticoid receptor beta. Mol Cell Biol. (2003) 23:4319-30. doi: 10.1128/MCB.23.12.4319-4330.2003

217. Oakley RH, Jewell CM, Yudt MR, Bofetiado DM, Cidlowski JA. The dominant negative activity of the human glucocorticoid receptor beta isoform. Specificity and mechanisms of action. J Biol Chem. (1999) 274:27857-66. doi: 10.1074/jbc.274.39.27857

218. Strickland I, Kisich K, Hauk PJ, Vottero A, Chrousos GP, Klemm DJ, et al. High constitutive glucocorticoid receptor beta in human neutrophils enables them to reduce their spontaneous rate of cell death in response to corticosteroids. J Exp Med. (2001) 193:585-93. doi: 10.1084/jem.193.5.585

219. Nwaneri AC, McBeth L, Hinds TD Jr. Sweet-P inhibition of glucocorticoid receptor $\beta$ as a potential cancer therapy. Cancer Cell Microenviron. (2016) 3:e1362. doi: $10.14800 / \mathrm{ccm} .1362$

220. Stechschulte LA, Wuescher L, Marino JS, Hill JW, Eng C, Hinds TD Jr. Glucocorticoid receptor $\beta$ stimulates Akt1 growth pathway by attenuation of PTEN. J Biol Chem. (2014) 289:17885-94. doi: 10.1074/jbc.M113.544072

221. Li LB, Leung DY, Hall CF, Goleva E. Divergent expression and function of glucocorticoid receptor $\beta$ in human monocytes and T cells. J Leukoc Biol. (2006) 79:818-27. doi: 10.1189/jlb.0805466

222. Filipovic D, Pirkmajer S, Mis K, Mars T, Grubic Z. Expression of glucocorticoid receptors in the regenerating human skeletal muscle. Physiol Res. (2011) 60(Suppl. 1):S147-54.

223. Ebrecht M, Buske-Kirschbaum A, Hellhammer D, Kern S, Rohleder N, Walker B, et al. Tissue specificity of glucocorticoid sensitivity in healthy adults. J Clin Endocrinol Metab. (2000) 85:3733-9. doi: 10.1210/jcem.85.10.6891

224. Walker BR. Glucocorticoids and cardiovascular disease. Eur J Endocrinol. (2007) 157:545-59. doi: 10.1530/EJE-07-0455
225. So AY, Chaivorapol C, Bolton EC, Li H, Yamamoto KR. Determinants of celland gene-specific transcriptional regulation by the glucocorticoid receptor. PLoS Genet. (2007) 3:e94. doi: 10.1371/journal.pgen.0030094

226. Oakley RH, Busillo JM, Cidlowski JA. Cross-talk between the glucocorticoid receptor and $\mathrm{MyoD}$ family inhibitor domain-containing protein provides a new mechanism for generating tissue-specific responses to glucocorticoids. $J$ Biol Chem. (2017) 292:5825-44. doi: 10.1074/jbc.M116.758888

227. Coutinho AE, Campbell JE, Fediuc S, Riddell MC. Effect of voluntary exercise on peripheral tissue glucocorticoid receptor content and the expression and activity of 11beta-HSD1 in the Syrian hamster. J Appl Physiol. (2006) 100:1483-8. doi: 10.1152/japplphysiol.01236.2005

228. LaPier TK. Glucocorticoid-induced muscle atrophy. The role of exercise in treatment and prevention. I Cardiopulm Rehabil. (1997) 17:7684. doi: 10.1097/00008483-199703000-00002

229. Tacey A, Parker L, Yeap BB, Joseph J, Lim EM, Garnham A, et al. Single dose prednisolone alters endocrine and haematologic responses and exercise performance in men. Endocr Connect. (2019) 8:1119. doi: 10.1530/EC-18-0473

230. Nagy Z, Marta A, Butz H, Liko I, Racz K, Patocs A. Modulation of the circadian clock by glucocorticoid receptor isoforms in the H295R cell line. Steroids. (2016) 116:20-7. doi: 10.1016/j.steroids.2016.10.002

231. Xu RB, Liu ZM, Zhao Y. A study on the circadian rhythm of glucocorticoid receptor. Neuroendocrinology. (1991) 53(Suppl. 1):316. doi: 10.1159/000125792

232. Quattrocelli M, Barefield DY, Warner JL, Vo AH, Hadhazy M, Earley $\mathrm{JU}$, et al. Intermittent glucocorticoid steroid dosing enhances muscle repair without eliciting muscle atrophy. J Clin Invest. (2017) 127:241832. doi: 10.1172/JCI91445

233. Morrison-Nozik A, Anand P, Zhu H, Duan Q, Sabeh M, Prosdocimo DA, et al. Glucocorticoids enhance muscle endurance and ameliorate Duchenne muscular dystrophy through a defined metabolic program. Proc Natl Acad Sci USA. (2015) 112:E6780-9. doi: 10.1073/pnas.1512968112

234. Haldar SM, Jeyaraj D, Anand P, Zhu H, Lu Y, Prosdocimo DA, et al. Kruppellike factor 15 regulates skeletal muscle lipid flux and exercise adaptation. Proc Natl Acad Sci USA. (2012) 109:6739-44. doi: 10.1073/pnas.1121060109

235. Wang J, Chen T, Feng F, Wei H, Pang W, Yang G, et al. KLF15 regulates slow myosin heavy chain expression through NFATc1 in C2C12 myotubes. Biochem Biophys Res Commun. (2014) 446:12316. doi: 10.1016/j.bbrc.2014.03.091

236. Jeyaraj D, Scheer FA, Ripperger JA, Haldar SM, Lu Y, Prosdocimo DA, et al. Klf15 orchestrates circadian nitrogen homeostasis. Cell Metab. (2012) 15:311-23. doi: 10.1016/j.cmet.2012.01.020

237. Masuno K, Haldar SM, Jeyaraj D, Mailloux CM, Huang X, Panettieri RA $\mathrm{Jr}$, et al. Expression profiling identifies Klf15 as a glucocorticoid target that regulates airway hyperresponsiveness. Am J Respir Cell Mol Biol. (2011) 45:642-9. doi: 10.1165/rcmb.2010-0369OC

238. Overman RA, Yeh JY, Deal CL. Prevalence of oral glucocorticoid usage in the United States: a general population perspective. Arthritis Care Res. (2013) 65:294-8. doi: 10.1002/acr.21796

Conflict of Interest: MF is an employee of and owns stock in Quest Diagnostics, which provides laboratory testing services.

The remaining authors declare that the research was conducted in the absence of any commercial or financial relationships that could be construed as a potential conflict of interest.

Copyright $\odot 2020$ Kraemer, Ratamess, Hymer, Nindl and Fragala. This is an openaccess article distributed under the terms of the Creative Commons Attribution License (CC BY). The use, distribution or reproduction in other forums is permitted, provided the original author(s) and the copyright owner(s) are credited and that the original publication in this journal is cited, in accordance with accepted academic practice. No use, distribution or reproduction is permitted which does not comply with these terms. 